Inclusive Labour Markets, Labour Relations and Working Conditions Branch

\section{Minimum wage setting practices in domestic work: an inter-state analysis}

Neetha N. *

* Centre for Women's Development Studies, New Delhi, India 

Copyright (๑) International Labour Organization 2015

Publications of the International Labour Office enjoy copyright under Protocol 2 of the Universal Copyright Convention. Nevertheless, short excerpts from them may be reproduced without authorization, on condition that the source is indicated. For rights of reproduction or translation, application should be made to the Publications Bureau (Rights and Permissions), International Labour Office, CH-1211 Geneva 22, Switzerland. The International Labour Office welcomes such applications.

Libraries, institutions and other users registered in the United Kingdom with the Copyright Licensing Agency, 90 Tottenham Court Road, London W1T 4LP [Fax: (+44) (0)20 7631 5500; email: cla@cla.co.uk], in the United States with the Copyright Clearance Centre, 222 Rosewood Drive, Danvers, MA 01923 [Fax: (+1) (978) 750 4470; email: info@copyright.com] or in other countries with associated Reproduction Rights Organizations, may make photocopies in accordance with the licences issued to them for this purpose.

\section{ILO Cataloguing in Publication Data}

Minimum wage setting practices in domestic work : an inter-state analysis / International Labour Office, Inclusive Labour Markets, Labour Relations and Working Conditions Branch. - Geneva: ILO, 2015

(Conditions of work and employment series ; No. 66)

International Labour Office. Inclusive Labour Markets, Labour Relations and Working Conditions Branch.

minimum wage / domestic work / women workers / wage determination / legal aspect / compliance / role of ILO / case study / regional level / India

13.07

First published 2015

Cover: DTP/Design Unit, ILO

The designations employed in ILO publications, which are in conformity with United Nations practice, and the presentation of material therein do not imply the expression of any opinion whatsoever on the part of the International Labour Office concerning the legal status of any country, area or territory or of its authorities, or concerning the delimitation of its frontiers.

The responsibility for opinions expressed in signed articles, studies and other contributions rests solely with their authors, and publication does not constitute an endorsement by the International Labour Office of the opinions expressed in them.

Reference to names of firms and commercial products and processes does not imply their endorsement by the International Labour Office, and any failure to mention a particular firm, commercial product or process is not a sign of disapproval.

ILO publications can be obtained through major booksellers or ILO local offices in many countries, or direct from ILO Publications, International Labour Office, CH-1211 Geneva 22, Switzerland. Catalogues or lists of new publications are available free of charge from the above address, or by email: pubvente@ilo.org

Visit our website: www.ilo.org/publns

Printed by the International Labour Office, Geneva, Switzerland 



\section{Table of contents}

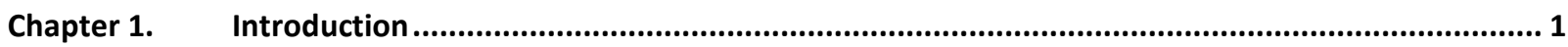

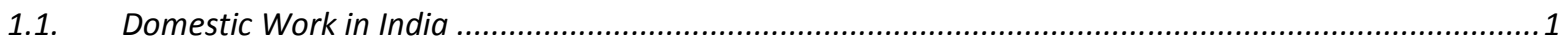

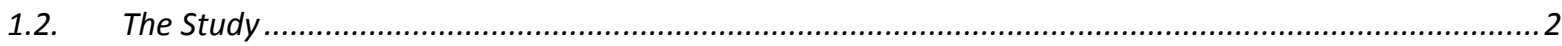

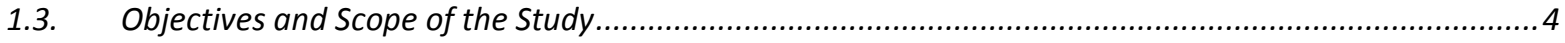

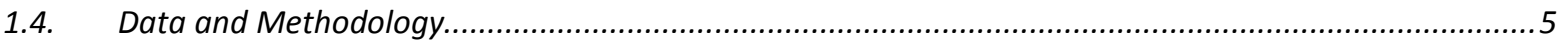

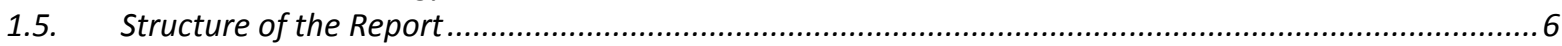

Chapter 2. The process, definition, wages, hours of work..................................................................... 7

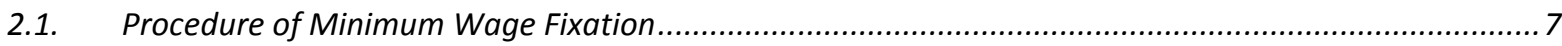

2.2. Definitional Variations in Domestic Work across Notifications ....................................................12

2.3. Fixation of Minimum Wage: Norms, Categories and Rates......................................................16

2.4. The Deadlock in the Case of Tamil Nadu .................................................................................21

2.5. Working Hours, Over Time, Rest Days and Other Provisions..........................................................22

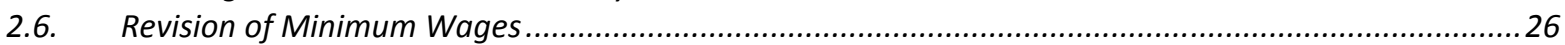

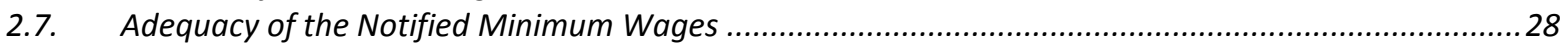

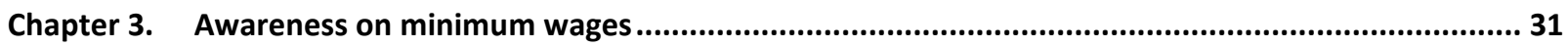

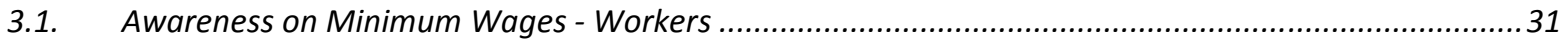

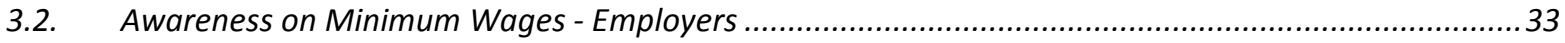

3.3. Awareness on Minimum Wages- Domestic Workers' Organisations / Trade Unions.............................34

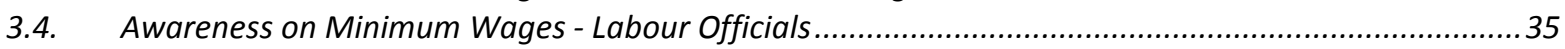

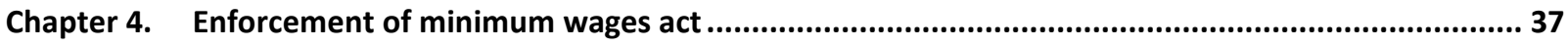

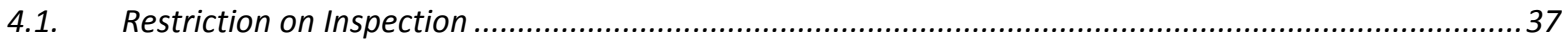

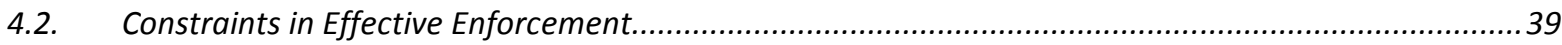

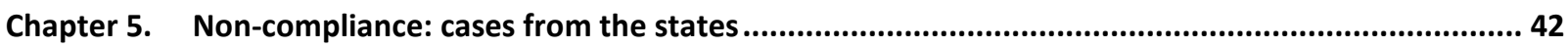

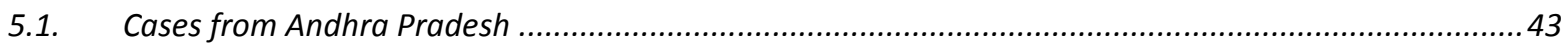

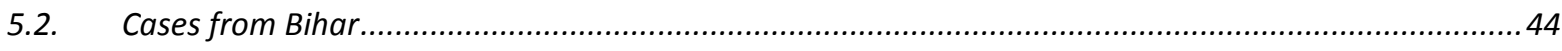

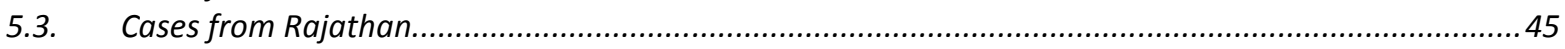

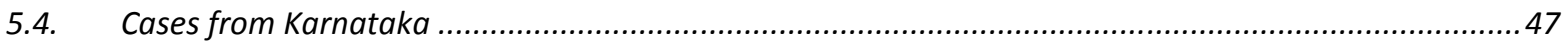

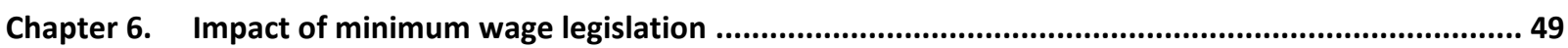

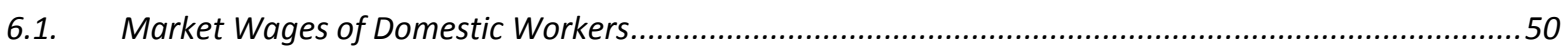

6.2. Hours of Work, Overtime Pay, Weekly Day of rest and Other Benefits .............................................55

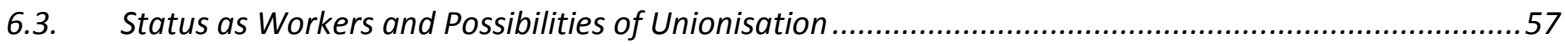

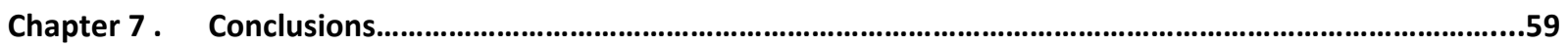

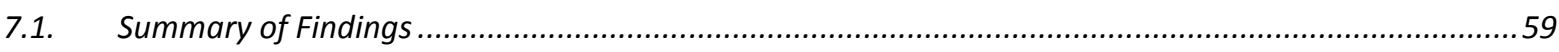

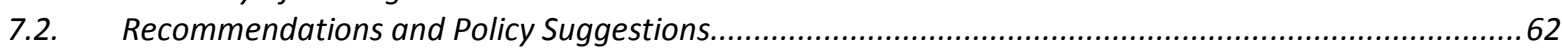

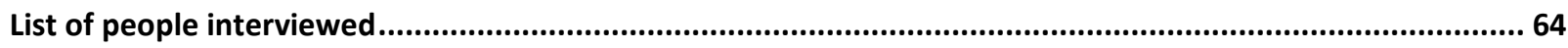

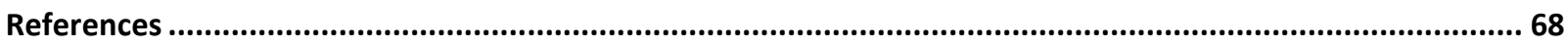

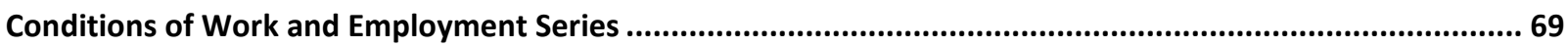




\section{List of tables}

Table 2.1. Minimum wage rate notification for domestic work -State wise details

Table 2.2. Details of stipulated duration and tasks in the legislation - State wise

Table 2.3. Details of latest (September 2012) minimum wage rates - State wise

Table 2.4. Comparison of daily wage rates for cleaning tasks - State wise (September 2012)

Table 2.5. Comparison of dearness allowance - State wise

Table 2.6. Comparison of working hours - State wise

Table 2.7. Comparison of over time and rest day - State wise

Table 2.8. Comparison of other provisions - State wise 25

Table 2.9. Karnataka: minimum wage rates, 2004 26

Table 3.1. Workers awareness on minimum wages - State wise (number of persons).

Table 6.1. Comparison of minimum wages for domestic work with market wages 50

Table 6.2. Minimum wages of domestic workers compared with comparable informal sector employment 


\section{Chapter 1. Introduction}

Domestic work is one of the growing sectors of women's employment across the world. However, the conditions of employment (including wages) have been documented to be one of the lowest. The sector is known for unstable and insecure jobs, with no social security. The regulation of the sector is also difficult due to existence of multiple employer-employee relationships and varied nature and conditions of work. The personal relations that differentiate the sector from the rest (largely arising out of private household spaces being the sites of employment), raise further challenges in regulating the sector. However, after the adoption of the ILO Convention on Domestic Work (C.189) in 2010 there has been some momentum in regulating the sector across the globe. Seven countries ${ }^{1}$ have ratified the ILO Convention and several countries have come out with progressive legislation protecting the interest of workers in the sector.

\subsection{Domestic Work in India}

The expansion and feminisation of domestic work is a relatively new phenomenon, in India. The estimates on domestic workers in India is highly contested ${ }^{2}-4.75$ million (Employment and unemployment NSS 61st round, 2004-05); 6.4 million (Census data 2001); and 90 million. ${ }^{3}$ The variation between the estimates suggests the informality and invisibility that embrace the sector. This could be due to several reasons, the main being under reporting arising out its 'non-work' status being an extension of household work. Irrespective of the sources of estimates, the number of domestic workers shows a huge increase over the period, leading to a further feminization of this occupation (Neetha, 2009). Estimates based on NSS data suggest that the number of female domestic workers showed a huge increase during the period 1999-00 and 2004-05. The increase has been more in urban areas though rural areas also show considerable expansion. During 2004-05, of the 4.75 million workers employed by private households, 3.05 million were in urban areas indicating the prominence of 'urban' in domestic work. ${ }^{4}$ However, the latest round of NSS employment unemployment data (2009-10) shows a substantial increase in the number of domestic workers in rural areas also.

On the basis of nature of employment, domestic workers are broadly divided into two - part time and full time workers. Full time workers are often further classified into live- in and live-out workers, while

\footnotetext{
${ }^{1}$ At the time of writing this paper, countries that had ratified C189 were: Uruguay, Philippines, Mauritius, Nicaragua, Paraguay, Bolivia and Italy.

${ }^{2}$ See Box 2.2 in Domestic workers across the world: Global and regional statistics and the extent of legal protection, ILO, 2012 for a detailed discussion on discrepancies between various sources on the estimates of domestic workers.

${ }^{3}$ Estimate in Task Force Report, 2011.

${ }^{4}$ Part of this increase may have been due to more careful enumeration with greater sensitivity to women's work and recognition of this category of workers. Though, there has been no change in the survey methodology during this period, the category 'others' within the broad category of 'community and personal services' of which domestic work is one category show a decline. However, this cannot fully explain this increase, which is also documented in many micro studies.
} 
all part time workers are live-out workers. Irrespective of the nature of employment, the employment and conditions of work are mostly informalised, with wages and working conditions varying considerably between workers in the same area or locality. Large populations of domestic workers are migrants from socially and economically vulnerable communities. The complexity of work organization, non uniform wage rates, absence of defined work hours, incidence of violence and sexual harassment are concerns in the context of decent work. The illiteracy, low caste and migrant status of workers further intensify the issue (Neetha, 2009; ISST, 2009). Lack of any labour welfare measures (such as health insurance, maternity protection, old age security), and the absence of possibilities of alternative employment leave them at the mercy of employers. The personal relations governing the entry to work and conditions of work, and the nature of workplace being the four walls of the house makes this sector qualitatively different from other sectors of informal employment. Apart from these labour market issues, a critical factor in the understanding of the sector is the social understanding of household work that is performed by domestic workers and its under-valuation in the larger social and economic level.

The sector is deprived of state regulation - be it in terms of labour legislation or social policies. Labour regulations have remained a challenge in the sector much more than any other informal sector due to the specificity of work and employee-employer relationship, and the workplace being private households. Domestic workers are excluded from the coverage of many core labour laws ${ }^{5}$ as they do not qualify for the definition of 'workmen', 'employer' or 'establishment' as defined in these laws. This demands extension of the definition of workplace, meaning a structural change in the formulation of labour laws in the country. In general, there is an overall reluctance to do so and accept home as a workplace. The government of India voted in favour of the adoption of the Domestic Workers Convention, which puts some obligation on the state to come up with legislation/policy protecting domestic workers.

\subsection{The Study}

In few states, because of pressure from organisations working among domestic workers coupled with the bureaucratic or political interest, there have been a few attempts to address poor working conditions of domestic workers through legislative interventions and extension of welfare schemes. Thus, some state governments have opted for including domestic work under the list of scheduled employment under the Minimum Wages Act, 1948 (MWA, 1948).

\footnotetext{
${ }^{5}$ Domestic workers are not included in the central list of scheduled employments under the Minimum Wage Act of 1948. Domestic workers are excluded from core labour laws such as Payment of Wages Act (1936), Workmen's' Compensation Act (1923), Contract Labour (Regulation and Prohibition) Act (1970) and Maternity Benefit Act 1961. These labour laws which were mostly drafted between 1930 and 1970, were intended for manufacturing units and classify every employee as workman who is defined as "any person employed in any industry to do any manual, unskilled, skilled, technical, operational, clerical or supervisory work". Since household is not identified as an industry domestic workers are outside the purview of these Acts. Though minimum wage law has been extended to domestic workers in some states, no amendments to other labour legislations toward including domestic work are made in any of the states. 
The Minimum Wages Act, 1948 is a labour Welfare legislation to prevent exploitation of unorganised workers by paying unduly low wages. ${ }^{6}$ It covers all employers who employ one or more workers in any scheduled employment in respect of which minimum wages have been fixed under the Act. ${ }^{7}$ The Act empowers the Appropriate Government to fix and revise the statutory rates of minimum wages for scheduled employments at intervals not exceeding five years. As per these provisions, until the end of 2012, minimum wages for domestic workers are notified only in six states- Karnataka, Andhra Pradesh Bihar, Rajasthan, Kerala and Jharkhand. Tamil Nadu is one state where though domestic work is included in the scheduled employment, a minimum wage rate is not yet fixed for the sector. Apart from these states, the matter of inclusion of domestic work within the purview of minimum wage has received mixed response. While some states are actively in the process ${ }^{8}$ of notifying minimum wages, in many others, the issue is yet far from the central stage.

Though in some of the states mentioned above minimum wages for domestic work have been in place for many years, little information is available on the process, the existing rates and their impact on the labour market. Setting of a statutory minimum wage in itself does not ensure any improvement in market wages and/or working conditions. It requires effective enforcement on the part of appropriate authorities, alongside awareness generation among workers. Preliminary information of the sectors suggests that there is a gap between the provisions of the law and its knowledge among potential beneficiaries, and the actual operation and coverage of the legislation. There are variations across states in the rate fixed, methods of wage fixation (time rate versus piece rate), definition of domestic work, awareness level, impact on overall wages and the role of organisations or unions of domestic workers. Thus, the process of setting and enforcement of minimum wages has not been optimal which necessitated an enquiry into the issues and constraints that affect the functioning of the legislation. It is this context that the present study was undertaken.

The aim of the study is to do a comparative analysis of the states that have notified minimum wages for domestic workers with a view to draw lessons from their experiences. The experiences of various states would help in delineating aspects of the law and its specificities that can make the intervention more meaningful. This would thus help in the formulation of best practices for wider application. Apart from these, the study also tried to capture broad outlines of the effect of statutory minimum wage intervention in terms of setting a wage floor and improving other conditions of work. Some broad issues of implementation such as a lack of awareness among various stake holders and specific enforcement

\footnotetext{
${ }^{6}$ India has also ratified the ILO Minimum Wage Fixing Machinery Convention, (C. 26), 1928 in 1955.

${ }^{7}$ Article 1 of the ILO Convention on Minimum wage (C. 26) requires ratified countries to maintain machinery where by minimum rates of wages can be fixed for workers employed in certain of the trades or parts of trades (and in particular home working trades) in which no arrangements exist for the effective regulation of wages by collective agreement or otherwise and wages are exceptionally low.

${ }^{8}$ For example, as per media reports and data gathered from field visit, in the states of Assam and Orissa, and Union Territory of Dadra \& Nagar Haveli the procedures towards inclusion of domestic work in the list of scheduled employment has begun.
} 
issues are also discussed in the study. ${ }^{9}$ The reservations / concerns and suggestions of concerned stake holders for effective formulation and enforcement of minimum wages taking into account the specific situation of the state as well the overall conditions of employment are also captured.

\subsection{Objectives and Scope of the Study}

Minimum wage rates for domestic work have been notified in many states for many years now. Karnataka was the first state to notify minimum wages for domestic work in 2004, two other states (Bihar and Andhra Pradesh) notified in 2007, Rajasthan in 2008 and Kerala and Jharkhand in 2010. However, so far there have been no attempts to analyse/compare the wage rates, the processes of wage fixation followed, roles of workers, employers and organisations/trade unions in the setting and revising the rates, enforcement issues and its overall impact on market wages and workers. State specific analyses help in the understanding of the micro socio- economic effect of the regulations at a crossregional level. Because of the prevailing socio-economic differences, it is likely that different states could yield different outcomes and issues with regard to minimum wage regulation. In this context, the overall objective of the study is to capture the specificities and the functioning of the minimum wages legislation in those states where the same has been extended to domestic workers (through a comparative analysis of these states). The specific objectives of the study are to:

1. Analyse the commonalities and differences at the state level in terms of processes of minimum wage legislation, its coverage, notified wage rates and other conditions of work as specified in the legislation.

2. Capture and compare the level of awareness among employers, workers and other social partners on the inclusion of domestic work under the MWA 1948 and its various provisions.

3. Document and examine possibilities and instances of violations of the Act with due focus on methods of grievance redressal (formal as well as informal).

4. Provide broad insights on the enforcement of MWA, 1948 in the sector at state levels and to delineate the limiting factors in the light of reported cases.

5. Provide inputs and suggest guidelines in formulating a replicable model for realising minimum wages and strengthening the existing interventions in the sector.

Further, the study also tries to capture some rough indications and snap shots on some of the questions which are important in the context of minimum wage legislation such as: Has minimum wage legislation in the sector led to a reduced demand for domestic workers? Can the existence of a minimum wage which is less likely to be enforced lead to any change in the market wage? What are the effects of

\footnotetext{
${ }^{9}$ Out of the six states where MWA exists, Jharkhand is not covered in the study as minimum wage in Jharkhand was announced only recently - in 2011. Jharkand was part of Bihar till 2008 and Bihar is one of the 5 states that are covered in the study. 
the presence of a minimum wage on other working conditions? Are there non -economic benefits of the prevalence of minimum wage legislations? Though the methodology of the study may not allow for a definite analysis and understanding on some of these issues, the findings could however give some outline of the overall patterns in the sector.

Given the above objectives, the specific aspects that are covered in the study include: the impetus for establishing minimum wages for domestic workers in different states; the year of minimum wage fixation and the process involved; definition of domestic workers in the legislation; the rates of minimum wages; the definition of part time/ full time workers; categorizations followed (such as "skilled" or "unskilled" work) if any; the frequency and method of revision of minimum wages; the issue of overtime; role of workers and organisations of domestic workers in minimum wage setting; level of awareness and process of awareness generation; the implementation and monitoring of the law; and mechanisms and procedures for grievance redressal. The study also gathered information on the market wages of domestic workers and other conditions of work.

The study was undertaken during a period of 6 months (June to December, 2012) and 6 states were taken up for detailed analysis..$^{10}$ The states selected for the study are: Andhra Pradesh, Bihar, Karnataka, Kerala, Rajasthan and Tamil Nadu. All the states except Tamil Nadu, had notified minimum wages for domestic work. In Tamil Nadu minimum wage notification has yet to take place, though the committee on minimum wage was formed and submitted a report suggesting minimum wage rates. Thus, in the context of Tamil Nadu, apart from gathering the information on the relevant issues above, details on the withdrawal of the state from the inclusion of domestic workers under the Act was also collected.

\subsection{Data and Methodology}

The study was based on both secondary and primary data collected from each of the selected states apart from the literature that exist on the sector. Copies of notifications (both preliminary and final) on minimum wages and its revisions were collected from the labour departments of the selected states. Apart from minimum wage notifications, copies of relevant papers related to the conditions of domestic workers which the concerned departments agreed to share with the researcher was also collected. Copies of responses to preliminary notifications on minimum wage and other memorandums and submissions on issues of domestic workers (if any) were also collected from various

\footnotetext{
${ }^{10}$ The study was initially designed to cover 5 states and 1 union territory -4 states (Andhra Pradesh, Bihar, Karnataka and Rajasthan) and 1 union territory (Dadra \& Nagar Haveli). After the initiation of the study, the study was expanded to include the state of Kerala as it was noted that the state had notified minimum wages in 2010 and the wages were differentially fixed for various tasks. Further, given the states long history of trade union movement it was thought important to look at the state which would give further insights into the gendered dimensions of this occupation. During the course of the study it was identified that in the Union Territory of Dadra and Nagar Haveli Minimum wage legislation is not yet extended to domestic workers. Though the draft of the preliminary notification was prepared for inclusion of domestic workers into the schedule in 2010 , there were no further developments. Hence the union territory was dropped from the study.
} 
organisations/unions working on the issues of domestic workers. Further, available studies/reports relevant for the states were also gathered from both unions/researchers and others concerned. Apart from these secondary documents, interviews and discussions were held with officials of the Labour Department in various states, members of various unions/organisations working among domestic workers and researchers/lawyers in the concerned states. In all the states selected for detailed analysis, discussions with a small group of domestic workers was also carried out to get a first hand understanding of the actual wage situation and conditions of work and also to gather their awareness of minimum wages. For capturing the awareness levels of minimum wages and its provisions more systematically, a small sample of 30 workers was surveyed in all the selected states using a predesigned questionnaire. Alongside this, information on the awareness of minimum wages was collected from 10 employers each in all these states -again through a pre-designed questionnaire.

\subsection{Structure of the Report}

The rest of the report is organised into 5 Chapters. Chapter 2 provides an overview and comparative analysis of the processes, definition and provisions on working conditions with respect to state level minimum wage legislations. Alongside this, the specific case of deadlock of the processes in Tamil Nadu (after its inclusion of the domestic work in the scheduled list) is documented. An extended discussion on the adequacy of the notified minimum wages across states is also attempted in this chapter. The next chapter provides a comparative analysis across states on the awareness levels of workers, employers and other stakeholders such as unions/organisers and labour officials. Chapter 4 focuses on the impact of the legislation on wages and other working conditions. The chapter highlights the positive gains of the intervention, the most important being the recognition of domestic service as a category of employment. Based on reported instances and discussions with grass root level organisers and workers, Chapter 5 documents and examines some case studies on violation of provisions of MWA. The subsequent chapter focuses on the issue of enforcement and highlights the issues and challenges in translating the fruits of the legal provisions to the targeted beneficiaries. Finally, Chapter 7 summarises and concludes the discussions with specific suggestions for effective policy formulation. 


\section{Chapter 2. The process, definition, wages, hours of work}

The Minimum Wages Act, 1948 empowers the Central and State Governments to fix and revise the minimum rates of wages payable to workers in scheduled employments. The Act applies to the list of employments that are included in Part I and II of the Schedule appended to the Act. The authority to include an employment in the schedule and to take steps for getting the minimum wages fixed or revised vests with the Government - Central or State. ${ }^{11}$ The list of employment in the schedule is revised normally by the respective government with a view to provide protection to all who are unorganised and vulnerable. Thus, there are often additions to the scheduled list of the Act both at the central and state level, with changing categories and new forms of employment. In the list of scheduled employment at the Central Government level, domestic work is not included, which means that minimum wage rate does not exist at the national level for domestic work.

The provisions of the Act (Section 27) empower the appropriate State government to add any employment to the Schedule, which in its opinion needs to have a minimum wage fixed. The procedure requires only a three-month prior notification by the state government in the official gazette followed by another notification adding to the schedule the said employment. ${ }^{12}$ Thus, in some states, domestic work has been added to the list of scheduled employment at the state level which enables the state to fix minimum wages for this employment. Once the employment is added to the list of scheduled employment under the Act, it is the responsibility of the state to fix a statutory minimum wage for the sector, through the process as prescribed under the Act. For the purpose of coordinating the work relating to minimum wage fixation and for advising the appropriate government on revising minimum wages, an advisory board exists at both central and state levels. The Central Advisory Board advises the Central and State Governments in the matters of the fixation and revision of minimum rates of wages as well as for co-ordinating the work of Advisory Boards. Advisory Boards are tripartite in nature and consist of persons nominated by the appropriate government representing employers and employees in the scheduled employments, (in equal number) and independent persons not exceeding one third of the total number of members.

\subsection{Procedure of Minimum Wage Fixation}

\footnotetext{
${ }^{11}$ Since India follows a federal structure with labour in the concurrent list state governments can also frame labour laws and can extent provisions of labour laws to categories of employment which are not included at the central level.

${ }^{12}$ However, in cases of those employments, which are not in the schedule but in which it can be proved that more than 1000 workers are employed, and they are working in sweated/ exploited conditions of labour, a representation can be made to the Labour commissioner who will then recommend the fixing of a minimum wage.
} 
The Minimum Wages Act, 1948 prescribes the basic procedure for setting minimum wages. The first step in setting wage rates under the Minimum Wages Act, 1948 is the inclusion of the occupation under the list of scheduled employment. Once the occupation is included in the scheduled list of employment, the state is bound to fix, wages for this employment. In (Section 5 of) the Minimum Wages Act, 1948, two methods have been provided for fixation/revision of minimum wages. ${ }^{13}$ These are the committee method and notification method. It is in the government's discretion to choose either of these methods or a combination of both. The government adopts the committee method when it feels that it does not have sufficient knowledge or information about the scheduled employment. Under the committee method, committees and sub-committees are set up by the appropriate governments to hold enquiries and make recommendations with regard to fixation and revision of minimum wages, as the case may be. If the government following this procedure revises the minimum wages then it will also have to consult the respective advisory board. The committees/sub-committees are composed of representatives of employers and employees although there is no exact sectional representation of the industry. If the government adopts the second method, notification method, enough knowledge about the scheduled employment in question is already available. In this method, government proposals are published in the Official Gazette for information of the persons likely to be affected so as to enable them to send in their representations. In the notification, the government has to specify a date not less than two months from the date of the notification during which time they are to consider the representations received if any. All categories of labour that will be affected by the wage fixation should be included in the proposal. After considering the advice of the committees/sub-committees if any or as the case may be and all the representations received within the specified date, the appropriate government should, before the date specified in the notification, fix/ raise the minimum wage for the scheduled employment in question by notification in the Official Gazette. This normally comes into force on expiry of three months from the date of the issue of the preliminary notification or from the date as specified in the notification.

The states where domestic work is in the list of scheduled employment under the Act till 2011 are: Karnataka, Andhra Pradesh, Kerala, Bihar, Rajasthan, Jharkhand and Tamil Nadu. In Karnataka, Andhra Pradesh and Kerala the role of union/organisations working among domestic workers was instrumental in bringing the sector under the Minimum Wages Act, 1948. In all these states there has been intense campaigning by unions/organisations involving political leadership and bureaucracy which ultimately resulted in the notification of wages. These unions/organisations were also part of the process of wage setting though indirectly. However, their engagement with the wage setting processes (which will be discussed later) varied across states.

\footnotetext{
${ }^{13}$ Article 3 of the ILO convention on minimum wage (C. 26) specify the minimum requirements for the wage fixing process: consultation with representatives of employers and workers, and with wage specialists; association of these persons in the operation of the wage machinery; the agreed minimum wages will be binding. 
In Bihar and Rajasthan, from discussions with concerned officials and stakeholders it was evident that direction from the Ministry of Labour at the Central level initiated the process of minimum wage fixation in both the states ${ }^{14}$. As one of the Joint labour Commissioners in Jaipur recollected, "Around 2006 a letter was received by the state department of labour from Ministry of Labour GOI, directing the state governments to notify minimum wages for domestic workers. It is this which triggered the fixation of wages. Minimum wage notification has nothing to do with the pressure of any organised move. The existing organizations were not strong enough to push for minimum wage" (Interview with Mr. C.B.S Rathore Joint Labour Commissioner, Jaipur, Rajasthan on $6^{\text {th }}$ October 2012).

Karnataka is the forerunner in extending the Minimum Wages Act, 1948 to domestic workers and the notification including domestic work in the scheduled list of employment was issued in 1992. However, it was de-notified in the subsequent year. Organisations working among domestic workers attribute this reversal to the counter political pressure by the employer class. However, in 2001, the sector was again included under the list of scheduled employments under the Act. In Kerala the notification including domestic work under the scheduled list came in May 2005 while in Andhra Pradesh, the employment was included in the Act in July 2006. It was in 2007, all other states included the employment under the scheduled list of Minimum Wages Act, 1948 - Bihar: March 2007; Rajasthan: July 2007. In Tamil Nadu notification regarding inclusion of domestic work under the Minimum Wage Act, 1948 came in August 2007.

As evident from the table below (Table 2.1.), there have been substantial differences across states in terms of the time period between the listing of domestic work in the list of scheduled employment and the draft notification of minimum wage rates. In Karnataka the draft notification fixing wage rates was issued in February 2004 and the final notification was issued in March 2004 with effect from 1st April 2004. In Andhra Pradesh the preliminary notification was issued in May 2007 and the final in December 2007 with effect from 1st December 2007. Preliminary notification on wage rates was issued in May 2009 in Kerala followed by the final notification in March 2010. In Rajasthan, the preliminary notification on minimum wage was published in July 2007 and the final notification was issued in May 2008. In the case of Bihar, the preliminary notification was issued in July 2007 followed by the final notification in December 2007.

\footnotetext{
${ }^{14}$ Based on the recommendation of the task force on Domestic work, the Ministry of Labour \& Employment had once again written to all state governments to notify minimum wages for domestic work. 
Table 2.1. Minimum wage rate notification for domestic work - State wise details

\begin{tabular}{|l|l|l|l|l|l|}
\hline States & $\begin{array}{l}\text { Inclusion in the } \\
\text { list of scheduled } \\
\text { employment }\end{array}$ & $\begin{array}{l}\text { Preliminary } \\
\text { notification of } \\
\text { wage rates }\end{array}$ & $\begin{array}{l}\text { Final notification } \\
\text { of wage rates }\end{array}$ & $\begin{array}{l}\text { Statutory } \\
\text { minimum wage } \\
\text { with effect from }\end{array}$ & $\begin{array}{l}\text { Latest Minimum } \\
\text { Wage Revision }\end{array}$ \\
\hline Karnataka & February 2001 & March 2001 & March 2004 & 1st April 2004 & $1^{\text {st }}$ April 2011 \\
\hline Andhra Pradesh & July 2006 & May 2007 & December 2007 & $\begin{array}{l}\text { 1st December } \\
2007\end{array}$ & January, 2012 \\
\hline Bihar & March 2007 & July 2007 & December 2007 & $\begin{array}{l}\text { 1st December } \\
\text { 2007 }\end{array}$ & March, 2010 \\
\hline Rajasthan & July, 2007 & July 2007 & May 2008 & 1st May 2008 & May 2012 \\
\hline Kerala & May 2005 & May 2009 & March 2010 & 1st April 2010 & No revision \\
\hline
\end{tabular}

Source: Government of Andhra Pradesh; G.O.Ms.No.116, Labour Employment Training \& Factories (Lab.II) Department, Dt.07.12.2007; Government of Andhra Pradesh; G.O.Ms.No.119, LET \& F (Lab.II) Dept, Dt.10.12.2007; Government of Andhra Pradesh; G.O.Rt.No.1417, Labour Employment Training \& Factories (Lab.II) Department, Dated:10.12.2010 ; Government of Andhra Pradesh; G.O.Ms.No. 60, Labour Employment Training \& Factories (Lab.II) Department, Dt.01.11.2011; Government of Bihar G.O. No.5/MW-401/2007/LR 776 dated 6th March 2007; Government of Bihar G.O. No.5/MW-401/2007/LR 4444 dated 5th December 2007; Government of Bihar G.O. No.5/MW-401/2007/LR 3527,3528 dated 29th September 2009; Government of Bihar G.O. No.5/MW-401/2007/LR 996 dated 10th March 2010; Government of Karnataka, G.O Notification No. KE 88 LMW 1998, dated 7-3-2001; Government of Karnataka, G.O Notification No. KE 88 LMW 2004, dated 12-3-2004; Government of Karnataka, G.O Notification No. KAE 16 LMW 2010, dated 6-4-2010; Government of Karnataka, G.O Notification No. KAE 17 LMW 2010, dated 25-1-2011; Government of Kerala, G.O No. 22393/E1/2006/Employment dated 30-5-2009; Kerala Gazette, Extraordinary, Volume 55, No. 576, 11 ${ }^{\text {th }}$ March 2010; Government of Rajasthan, G.O F. 5 (1) /Labour/IR/95-part dated 28-7-2007; Rajasthan Gazette, Extraordinary, May 26, 2008 ratifying G.O F. 5 (1) /Labour/IR/95-part dated 28-7-2007; Government of Rajasthan, G.O F. 5 (6) /Labour/2002/Part dated 26-4-2012; Rajasthan Gazette, Extraordinary, August 6, 2012 ratifying G.O F. 5 (6) /Labour/2002/Part dated 26-4-2012 .

All states which fixed minimum wages had followed the notification method. However, the actual process of wage setting was different across states with respect to the following: nature and scope of consultation with stake holders, whether or not domestic workers of representatives were consulted and the criteria used in the setting of wage rate.

In Karnataka, the preliminary wage rates were arrived at through taking into account the cost of living and basic caloric intake. ${ }^{15}$ The preliminary notification invited suggestion/objection from various stake holders for two months which is mandatory. The suggestion from the unions was with regard to higher wage rates and accounting for employers' household size. The draft was modified incorporating the suggestions of accounting for the family size of employers and physical area of their houses. This was put forward to the advisory board for consideration. Based on the suggestions of the Minimum Wage Advisory Board the final minimum wages were arrived at. The constitution of the Minimum Wage Advisory Board committee is tripartite - with representatives from employers, employees and government. The government members are called independent members and the meeting is chaired by the Labour Secretary. The Labour Commissioner is the Coordinator of the committee, who conducts the meeting. The advisory board once constituted is normally functional for 2-3 years and looks into all the sectors considered for fixing/revising minimum age rates during this period. Though all the members

\footnotetext{
${ }^{15}$ As per conservation with Mr. Jingalappa, Joint Labour Commissioner, Bangalore, Karnataka. The impossibility of doing a time and motion study of domestic work which is otherwise one of the methods of arriving at a minimum wage rate was explained as the reason as to why no committee was formed to arrive at the minimum wage rate.
} 
representing workers in the Board were from large trade unions, one office holder of the Karnataka Domestic Workers Union (KDWU) was also invited as a special invitee to the meeting. As regards employers, the usual members from industries were present. ${ }^{16}$ The discussions with the member from the KDWU suggest that there was not much discussion on domestic workers as all the larger trade unions and employers were disinterested in the issues of domestic workers. This led to the acceptance of the wage rates suggested in the preliminary notification though the KDWU member argued for higher rates. Apart from rates, as per the KDMU member, there were no discussions on other provisions and everything was approved as given in the preliminary notification.

In Andhra Pradesh too, similar issues in fixing wage rates were highlighted during discussions with organisations working among domestic workers in Hyderabad. Though a few meetings were held by the labour department with the concerned stakeholders prior to and after the issue of the preliminary notification, none of the domestic workers union representatives or workers were invited to the Minimum Wage Advisory Board (MWAB) Meeting. The union members in the tripartite board during the discussion of fixing wage rates for domestic workers comprised only of members from major trade unions, who were not involved in the organising of domestic workers. However, the demand for a higher minimum wage, which was raised by domestic workers unions/organisations taking into account the increasing cost of living in their response to the draft, was discussed in the meeting and taken into account. This was highlighted by some of the organisations and the rates differed substantially between the draft and the final notification. ${ }^{17}$

In Bihar as in the case of Andhra Pradesh, the draft notification was initiated by the labour department and was published in the official gazette inviting suggestions and comments. The rates as per discussions with labour officials were decided taking into account existing minimum wage rates for unskilled work categories and cost of living. However, it was clear from the discussions with labour officials and organisations of domestic workers that there has been no input given on the draft notification by any stake holders. This was attributed to the lack of interest among the larger trade unions on the issues of domestic workers and to the absence of alternative active unions of domestic workers. Though the National Domestic Workers Movement (NDWM), Bihar had started its work in Patna at that time it was never consulted in the process and thus was unaware of any deliberations. The only major suggestion that came up in the MWAB meeting as per official records ${ }^{18}$ was to replace the word 'domestic servant' by 'domestic worker'. Accordingly, the term servant was rephrased in the final notification. No changes appeared in the wage rates between the two notifications.

\footnotetext{
${ }^{16}$ As per labour officials with whom the issue was discussed the constitution of employers in the context of domestic work is alright since they also employ domestic workers in their respective private households.

${ }^{17}$ While the monthly rates for 1 hour work was Rs. 244 and for 8 hour was Rs. 1950, in the final notification the same was Rs. 325 and 2600 respectively.

${ }^{18}$ Minutes of the MWAB meeting. 
In Rajasthan too the process reported was similar though it is not clear whether the rates were discussed in a formal Minimum Wage Advisory Board or not. As per the information shared by the labour commissioner, the wage rates were arrived at after considering the cost of living. The notification clearly says that the government has looked into the critical comments received on the draft before finalization of the rates (Rajasthan Annexure -1). However no difference is seen between the draft notification and the final notification.

In the state of Kerala the process was much more elaborate though at the broader level the same process was followed. After the preliminary notifications in 2009, the Minimum Wage Advisory Board held meetings in four districts of the state, namely, Trivandrum, Calicut, Ernakulam and Trichur, with workers, organisations of domestic workers who were not registered under the Trade Union Act and union members. Written response to the draft notification was also invited. Based on the meetings and written inputs from various stakeholders the final rates and conditions were prepared in a meeting of the board members. Interestingly, there were many concrete suggestions, including definition, rates, working conditions and a proposal to bring in uniformity across areas (distinction in minimum wage between Corporation, Municipality and Panchayat were made in the preliminary notification) ${ }^{19}$. But in Kerala too, the Board did not have any representative from the unions or organisations who were familiar with the issues of domestic workers.

From the above discussion it is evident that the processes in the States studied were characterized by absence or little consultation with domestic workers or with their employers, or with their representatives even where they existed (organisations of domestic workers or those working with them); low level of deliberations, if any, among board members on wage levels and other related conditions; and lack of clarity about the criteria and bases for setting the MW for domestic workers. Thus the process of minimum wage fixation has been largely a one-sided affair. The unfamiliarity of the organisations with the procedural and administrative requirements and formalities of the process of minimum wage fixation could be one of the factors that explain their passive role in minimum wage setting. On the other hand, there was no comprehensive effort from the part of the bureaucracy to involve workers or organisers of domestic workers in any of these states, except Karnataka. The lack of understanding and engagement with the specificity of the sectoral issues is clear when one analyzes the wage rates and other provisions of the notifications.

\subsection{Definitional Variations in Domestic Work across Notifications}

In setting up the minimum wage it is important to define the occupation in order to effectively operationalise the regulation. This is especially true for a sector like domestic work which otherwise is

\footnotetext{
${ }^{19}$ See Kerala Annexure - 1 (b) for details.
} 
understood as tasks that women have been traditionally performing without pay. Further domestic work is not homogenous and includes multiple tasks performed within an employment relationship. The most important characteristic that bind these multiple tasks is that they are performed for or in a private household or households, which makes it broad enough to accommodate the diverse tasks involved. ${ }^{20}$

However none of the state notifications define the occupation in terms of employment relationship or as employment within private households. All the state notifications define domestic work in terms of tasks undertaken. However, the tasks listed vary across states though at the overall level some uniformity exists among most of the states. Except in the state of Kerala, domestic work is defined in terms of the traditional gendered understanding of house work such as cleaning, cooking and basic care. No other state except Kerala lists driving, gardening or private security guards in the notification under the list of tasks. The tasks listed in the minimum wage notification in Kerala broadly cover all the tasks that are performed for private households. Even in Kerala, the preliminary notification had only 'driver' apart from the traditional house work tasks. The other categories gardener and security guards were added to the list on the recommendation of the Minimum Wage Advisory Board, which took into consideration the need to cover all workers working for or in private households. ${ }^{21}$

The part-time nature of domestic work is acknowledged in the fixing of wage rates -by either specifying the hourly rates or providing for the calculation of hourly wage rates from monthly rates. However, in all the notifications there is a lack of appreciation of the existence of live-in workers and their specificities leading to the defining of the rate in terms of eight (8) hours of work and by ignoring the issue of overtime completely or casually providing for overtime wages as in the case of other industries.

\footnotetext{
${ }^{20}$ This is in line with the ILO Domestic Workers Convention 2011 (No.189), Article 1. A "domestic worker" is defined in Convention No. 189 as "any person engaged in domestic work within an employment relationship" (Art. 1(b)). Domestic work thus may involve a range of tasks, including cooking, cleaning the house, washing and ironing the laundry, general housework, looking after children, the elderly or persons with disabilities, as well as maintaining the garden, guarding the house premises, and driving the family care.

${ }^{21}$ This is clear from the minutes of the Minimum wage advisory board meeting. 
Table 2.2. Details of stipulated duration and tasks in the legislation - State wise

\begin{tabular}{|c|c|c|}
\hline States & $\begin{array}{l}\text { Rates fixed for } \\
\text { duration }\end{array}$ & Tasks listed in the notification \\
\hline Karnataka & Per day -8 hours & $\begin{array}{l}\text { Washing the clothes / washing the utensils / housekeeping and looking } \\
\text { after the children / and other work }\end{array}$ \\
\hline Andhra Pradesh & $\begin{array}{l}1 / 2 \text { hour; } 1 \text { hour; } 1 \frac{1}{2} \\
\text { hours; } 8 \text { hours }\end{array}$ & $\begin{array}{l}\text { Cleaning of vessels / washing of the clothes / sweeping and swabbing } \\
\text { floor / baby sitting / care of old or infirm persons / kitchen shopping / } \\
\text { taking children to school and back / other household chores }\end{array}$ \\
\hline Bihar & 1 hour; 8 hours & $\begin{array}{l}\text { Washing the clothes / washing the utensils / house keeping and looking } \\
\text { after the children / and taking to school and back / other miscellaneous } \\
\text { domestic works }\end{array}$ \\
\hline Rajasthan & 1 hour; 8 hours & $\begin{array}{l}\text { Washing clothes and vessels and sweeping and moping / child care / } \\
\text { taking children to school and back and other household work }\end{array}$ \\
\hline Kerala & $\begin{array}{l}1 \text { hour; }>1 \text { hour } \&<5 \\
\text { hours; } 8 \text { hours; } \\
\text { monthly }\end{array}$ & $\begin{array}{l}\text { Washing clothes / washing utensils / sweeping and cleaning house } \\
\text { premises and moping / shopping of vegetables and items related to } \\
\text { cooking / cooking assistance / taking care of children and taking them to } \\
\text { school / taking care of elderly, disabled etc. / cooking / any other } \\
\text { household work / driving of personal cars / gardening and assistance / } \\
\text { home nursing / working as security / watch man }\end{array}$ \\
\hline
\end{tabular}

Source: Same as Table 2.1

The tasks listed in the notifications are reflections of the larger social understanding of what constitutes domestic work, which is limited to traditional housework such as cleaning, cooking, child and elderly care. This social definition of domestic work was commonly shared by trade unions, organisations of domestic workers, employers, workers and labour officials across states. The understanding of domestic work across states among various stakeholders was more or less precise and uniform, as work performed for the private household such as housekeeping (cleaning tasks \& cooking), child care and other personal care. In their understanding, domestic workers comprised of all part-time, full-time and live-in workers engaged in the above tasks while employers were understood as those who employed them to undertake these tasks. 'Shopping for the household', if done alongside other household work such as cooking, cleaning etc., was also taken as domestic work.

The other categories of domestic workers such as gardeners, personal drivers and 'watchmen'/guards were mostly not treated as domestic workers. For many, these categories do not figure in their social understanding of the term domestic work and hence do not have any strong opinion on the matter. Though some respondents especially those who are familiar with the Domestic Workers Convention, 2011 (No. 189) theoretically agreed on the broader definition which includes gardeners, drivers etc., it was felt that in the context of India it was better to limit the definition to the most widely understood tasks of domestic workers. For a small group of organisations working among domestic workers, the non-inclusion of such tasks into their definition of domestic work was due to the labour market characteristics of such tasks. These occupations were largely dominated by men and their employment relations were more formal with better conditions of pay than occupations mainly performed by women. Their inclusion was thus argued to have an invisibilising impact on the issues of the major segment of workers, who are largely women. Organisations also pointed out that though minimum wage protection 
at present was not extended to male dominated domestic work tasks in many of these states, the market wages for such tasks were much above that of female domestic workers wage who undertook mostly traditional house work. Further, it was suggested that the tasks performed by men within private households did not have the issue of non recognition and undervaluation which characterized other female dominated tasks and thus had other possibilities for organised labour demands. Hence it was thought strategic to separate the two though after attaining certain minimum rights one could think of including them in this category. ${ }^{22}$

All the labour administrators (with whom the issue was discussed) were also aware of the discussions on the broader definition of domestic work and did not express any specific concern in their inclusion into the list. However, some did highlight the possibility of the issues of female domestic workers, who are largely into traditional housework, getting diluted if other male-dominated tasks, such as driving, guarding and gardening, are included in the list, on the lines of the union position.

When the question was asked to domestic workers, many did not see these workers as fellow workers with clear differentiation. The fact that their workplace is outside the 'home' though sometimes in the premises was pointed out as the central point which differentiated their work from the usual domestic work. Interestingly, many men who were drivers, gardeners etc. with whom informal discussion was held, though expressing the desire to be included in the minimum wage coverage did not want their occupation to be clubbed into the overall category of domestic work as this, they thought, would degrade their current status.

On care tasks, there was an obvious division that came out in the discussions with unions as well as workers and policy makers - between the larger segment of work that did not demand any technical skills and the smaller but growing demand for specialised care that required formal technical skills. The first, especially child care, is performed by a large number of domestic workers either on a day-to-day basis or occasionally. Child care is listed in all the notifications across states while old age care and care of the sick figure only in the notifications of Andhra Pradesh and Kerala. In all the states except Kerala the specialised group of care workers (in Kerala, the category of home nurse) does not figure in the list of activities. In Kerala's minimum wage notification, a distinction is made between the general care tasks and specialised care demanding technical expertise with different wages for these categories. Policy makers at large and unions of domestic workers were in particular unanimous on the need to separate specialised care work from care services delivered by non-technical workers. The suggestion

\footnotetext{
${ }^{22}$ Interestingly, one organisation working among domestic workers in Bihar - Naukar Dai Sangh - when asked about the naming of the organisation and its degradation of domestic work elaborated the problem of social distancing of organisations by domestic workers. It was explained that many domestic workers themselves do not consider them as workers as the social structure that they live and work do not see them as workers. This is not only an issue of employers but also of the workers 'a baggage of the social system'. Thus by naming an organisation by what could be progressive does not help in organising domestic workers. Since workers are more comfortable with this concept/usage they are more easily attracted and better able to relate to this organisation, paving the path to larger social change.
} 
was to include specialized care work (as they are technically qualified) in the categories of occupations in a hospital setting by making a distinction between institutional and household spaces if required. This clearly reveals the social understanding of domestic work tasks as non- technical and non-skilled occupation which was shared by all the stakeholders. Surprisingly, unions or organisations working among domestic workers though advocate for recognizing domestic work as skilled work also argued for such divisions.

On the whole, there are reservations among unions and organisations working among domestic workers on the inclusion of specialized care tasks and tasks such as gardening, ironing, driving etc. into the minimum wage notification for domestic work. These reservations, more than the practical impact of a broader definition on women workers, are based on the social understanding of domestic work. This is evident from their position on specialized care tasks, as explained above which are dominated by women in all the states.

\subsection{Fixation of Minimum Wage: Norms, Categories and Rates}

The Minimum Wages Act, 1948 provides for the fixation of (a) a minimum time rate; (b) a minimum piece rate; (c) a guaranteed time rate; (d) an overtime rate appropriate to different occupations and different classes of workers. As per the Act, the minimum wages fixed or revised by the appropriate government include: (a) a basic rate of wages and a special allowance at a rate to be adjusted, at such intervals and in such manner as the appropriate government may direct, to accord as nearly as practicable with the variation in the cost of living index number applicable to such workers, ${ }^{23}$ (b) a basic rate of wages with or without the cost of living allowance and the cash value of the concessions in respect of suppliers of essential commodities at concession rates, where so authorised: or; (c) an all inclusive rate allowing for the basic rate, the cost of living allowance and the cash value of the concessions, if any.

\section{Norms for Calculating Minimum Wage}

Five norms for fixing minimum wages were established by the 15th Indian Labour Conference (ILC) in 1957 - that minimum wages should be high enough to meet all basic needs of a worker's family, including food, clothing, shelter and other amenities. According to the 15th ILC, in calculating the minimum wage:

- the standard working class family to be taken as three consumption units for one earner, which is two adults and two children;

\footnotetext{
${ }^{23}$ Cost of living index number in relation to employees in any scheduled employment in respect of which minimum rates of wages have been fixed, means the index number ascertained and declared by the competent authority by notification in the Official Gazette to be the cost of living index number applicable to employee in such employment.
} 
- $\quad$ minimum food requirement to be taken as a balanced diet of 2,700 calories per day per consumption unit;

- clothing requirement to be based on per capita consumption of 18 yards per annum, which gives 72 yards per annum for the average worker's family;

- for housing, the rent corresponding to the minimum area provided for under the government's industrial housing schemes should be taken; and

- fuel, lighting and other items of expenditure should constitute 20 per cent of the total minimum wage;

- the Supreme Court fully upheld these criteria in the case of Unichoy vs. State of Kerala in 1961. In the later Reptakos Brett vs. Workmen case in 1991, the Supreme Court held that minimum wages should also include a sixth component, amounting to $25 \%$ of the total minimum wage, to cover children's education, medical treatment, recreation, festivals and ceremonies. ${ }^{24}$

The State Governments have been requested from time to time to keep the above norms and judicial pronouncement in view while fixing/revising the minimum wages.

Wage rates as prescribed by the Act do not suggest any clear method of calculation followed, though in all the states the rates were assumingly fixed taking into account the cost of living and basic caloric intake. This arbitrariness in terms of fixing the minimum wage rates for domestic work has been pointed out by organisations. ${ }^{25}$

There has been variation across States in the minimum wage rates as is evident from the following table (Table 2.3). The variation of minimum wages between the States could be due to differences in socioeconomic and agro-climatic conditions, prices of essential commodities and other local conditions influencing the wage rate. However, none of these fully explain the difference between Karnataka and Kerala. Kerala has the lowest rates and Karnataka has the highest if daily and monthly rates are taken.

In Andhra Pradesh, Bihar and Rajasthan all tasks have the same minimum wage rates. Karnataka has two separate wage rates, with a higher wage rate for housework with child care. However, cooking is missing from the list of tasks. Kerala differentiates wage rates for various tasks under domestic work in accordance with the social understanding of the hierarchy among domestic tasks, though the rates do not differ much across these tasks. Thus, cleaning work has the lowest wage rate though the difference in wage rates between routine cleaning work and non-specialised care work for an hour is just 50

\footnotetext{
${ }^{24}$ If one goes by Patnaik's estimation of poverty line, at least Rs.1,085 a month and Rs.1,800 a month are required in rural and urban areas respectively (Patnaik, 2011). If one assumes that the average worker has to support four members (which is on the lower side), then Rs. 4340 and Rs. 7200 is the minimum monthly household income required to be out of poverty line. If we add 25 percent of this for education and other expenses then the same would be Rs. $5425 \& 9000$ in rural and urban areas respectively.

${ }^{25}$ For details of this please see Domestic Worker Productivity: A Rationale, Stree Jagruti Samiti, 2005. 
paise. ${ }^{26}$ Cooks, security guards and workers engaged in gardening activities share the same minimum wage but it is higher than that of cleaning and care workers. Drivers, gardeners and home nurses have the highest wage rate. However, the difference in wage rates between the highest paid task and the lowest paid task on a day for an hour is just Rs. 2. This makes it clear that more than the monetary differences in wages, it is the social understanding of that task that notification is primarily bringing out. In the Kerala notification, wages rates have been fixed differently for first one hour and additional hours till 5 hours. Payment for additional hours is less compared to the first one hour. However, it provides for 8 hours wages if the worker works with one employer continuously for more than 5 hours. Further, the notification also directs additional payment if there are more than 4 adult members in the household where only one worker is employed. Wages are increased as per the number of such adult members by 5 percent to a maximum of 15 per cent. Rajasthan also suggests an additional payment of 10 per cent per member for more than 4 members in the family. This provision for additional payment (10 per cent) based on the household size was originally in the Karnataka Notification but was not included in the revised notification.

Table 2.3. Details of latest (September 2012) minimum wage rates - State wise

\begin{tabular}{|c|c|c|}
\hline States & Tasks & $\begin{array}{l}\text { Current Wage Rates } \\
\text { (Monthly) }\end{array}$ \\
\hline Karnataka & $\begin{array}{l}\text { Washing the clothes / Washing the Utensils/ Housekeeping and cleaning } \\
\text { of house. } \\
\text { Washing the Utensils / Washing the clothes / House Keeping and looking } \\
\text { after children }\end{array}$ & $\begin{array}{l}8 \text { hours - } 165.58 \text { (Daily) } \\
8 \text { hours - } 170.58 \text { (Daily) }\end{array}$ \\
\hline $\begin{array}{l}\text { Andhra } \\
\text { Pradesh }\end{array}$ & $\begin{array}{l}\text { Cleaning of vessels / washing of the clothes / sweeping and swabbing } \\
\text { floor / babysitting / care of old or infirm persons / kitchen shopping / } \\
\text { taking children to school and back / other household chores }\end{array}$ & $\begin{array}{l}1 / 2 \text { hour }-284 \text { (Monthly) } \\
1 \text { hour }-565 \text { (Monthly) } \\
1 \frac{1}{2}-848 \text { (Monthly) } \\
8 \text { hours }-4521 \text { (Monthly) }\end{array}$ \\
\hline Bihar & $\begin{array}{l}\text { Washing the clothes / washing the utensils / housekeeping (a house of } \\
1000 \text { square feet) and looking after the children / and taking to school } \\
\text { and back / other miscellaneous domestic works }\end{array}$ & $\begin{array}{l}1 \text { hour- } 470 \text { (Monthly) } \\
8 \text { hours- } 3749 \text { (Monthly) }\end{array}$ \\
\hline Rajasthan & $\begin{array}{l}\text { Washing clothes and vessels and sweeping and moping / child care / } \\
\text { taking children to school and back and other household work }\end{array}$ & $\begin{array}{l}60 \text { minutes }-543 \text { (Monthly) } \\
8 \text { hours- } 4342 \text { (Monthly) }\end{array}$ \\
\hline Kerala & $\begin{array}{l}\text { Washing clothes / Washing utensils / Sweeping and cleaning house, } \\
\text { premises and moping / Shopping of vegetables and items related to } \\
\text { cooking / Cooking assistants / other household work }\end{array}$ & $\begin{array}{l}\text { Per hour - } 26.25 \text { (Daily) } \\
\text { Additional hours till } 5 \text { hours - } \\
15 \text { (Daily) } \\
8 \text { hours - } 136.50 \text { (Daily) } \\
\text { Monthly wage - } 3549 \\
\text { Per hour - } 26.75 \text { (Daily) } \\
\text { Additional hours till } 5 \text { hours - } \\
15.50 \text { (Daily) }\end{array}$ \\
\hline
\end{tabular}

${ }^{26} 100$ paise is equivalent to one Indian rupee. 


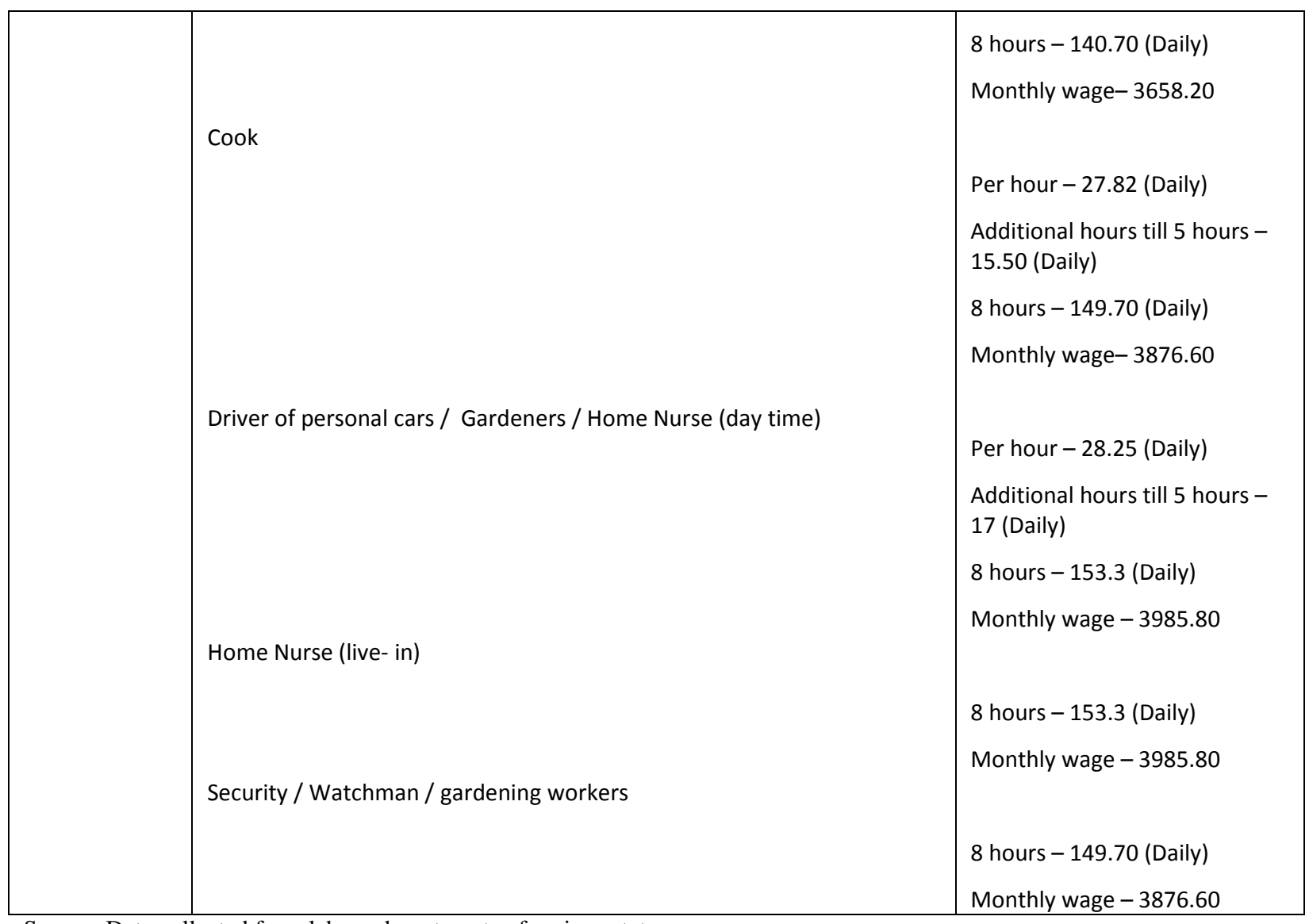

Source: Data collected from labour departments of various states

The task-based differentiation in minimum wages is more complex than it seems to suggest when the social profile of workers performing these tasks are analysed. The rates when differentiated across tasks assume a class hierarchy in establishing minimum wages. There exists a considerable degree of segregation in terms of tasks along caste lines in all the states though the degree to which such notions exists varies not only between states but also by rural/urban distinction and local parameters. Cleaning tasks are considered as one general task - though sometimes cleaning utensils and washing clothes are considered better in terms of status compared to sweeping with a broom and mopping floors. The presence of lower castes in cleaning operations was the highest in all the states. But in many states they were also engaged in cooking but their proportion in this task is much less compared to cleaning. The presence of upper castes in tasks involving only sweeping and mopping was reported the lowest, though some combined these tasks with cooking.

The complexity involved in minimum wage setting becomes more apparent if one calculates the differences in daily wage rates for different hours for different states based on the statutory minimum wage. The following table (Table 2.4) gives the differential wage rates for different states for various hours of work on a daily basis. For Andhra Pradesh, Bihar and Rajasthan, the calculation is simple as the notification gives monthly wages for an hour of work. For these states, the monthly wages are divided by 26 days ( 4 days being mandatory weekly offs/rest days) to arrive at the daily hourly rates. 
For Karnataka, the rates are given for 8 hours work in a day, and hourly rates are calculated by dividing the daily rate by 8 . Kerala gives daily rates for different durations of work separately in the notification. The following table gives daily wage rates calculated for cleaning tasks in different states.

Table 2.4. Comparison of daily wage rates for cleaning tasks - State wise (September 2012)

\begin{tabular}{|l|l|l|l|l|l|}
\hline State & $\mathbf{1}$ hour & $\mathbf{2}$ hours & $\mathbf{5}$ hours & $\mathbf{6}$ hours & $\mathbf{8}$ hours \\
\hline Karnataka & 20.70 & 41.40 & 103.5 & 124.20 & 165.58 \\
\hline Andhra Pradesh & 21.73 & 43.46 & 108.65 & 130.38 & 173.85 \\
\hline Bihar & 18.08 & 36.15 & 90.38 & 108.46 & 144.62 \\
\hline Rajasthan & 20.88 & 41.77 & 104.42 & 125.31 & 167.08 \\
\hline Kerala & 26.25 & 41.25 & 86.25 & 136.50 & 136.50 \\
\hline
\end{tabular}

Source: Estimated from Table 2.3.

Hourly wage rates are very important as a large section of the domestic workers are part-time workers, who may work for a particular employer only for short durations. Thus if a worker works only for an hour in a day then the wage rate is highest in Kerala. For cleaning tasks, the rate for an hour of work is roughly Rs. 21 in Karnataka, but Rs. 26.25 in Kerala. Since Kerala has differential hourly wage rates this advantage disappears for a duration above one hour as the rates are lower for additional hours.

In Karnataka, unions and organisations working among domestic workers have pointed out the neglect of the concerns of part-time workers in the notification. Many part-time workers, though they work for eight hours or more in a day, work for multiple employers mostly with duration of half an hour to two hours. The worker may finish as many tasks as possible in the limited time by over-straining, which would enable her/him to cover multiple houses in a day to make a living. The current minimum wage setting clearly disadvantages them when hourly minimum wage is calculated from the statutory 8-hour daily wage. This put part-time workers who work in multiple houses at the risk of both self-exploitation and exploitation by employers.

\section{Dearness Allowance}

It was recommended in the Labour Ministers' Conference held in 1988, to evolve a mechanism to protect wages against inflation by linking it to the rise in the Consumer Price Index. The Variable Dearness Allowance came into being in the year 1991. However, dearness allowance (DA) was not included in the calculation of minimum wages in two states till recently - Andhra Pradesh and Bihar. In Bihar DA was introduced in 2009 while in Andhra Pradesh DA was included when the minimum wage rates were revised in 2011. In Andhra Pradesh, organisations working among domestic workers have 
campaigned for providing D.A revisions for domestic workers. In all the states, DA is now applicable to domestic workers. In some states DA revisions are done annually while in other states the same is revised every six months.

Table 2.5. Comparison of dearness allowance - State wise

\begin{tabular}{|l|l|}
\hline States & DA \\
\hline Karnataka & DA calculated annually \\
\hline Andhra Pradesh & $\begin{array}{l}\text { No provision for DA till revision in } 2011 ; \text { revision every six months }-1^{\text {st }} \text { April \& } 1^{\text {st }} \\
\text { October }\end{array}$ \\
\hline Bihar & No DA till 2009; revision every six months $-1^{\text {st }}$ April \& $1^{\text {st }}$ October \\
\hline Rajasthan & DA calculated annually \\
\hline Kerala & DA revision every six months; $1^{\text {st }}$ April $\& 1^{\text {st }}$ October \\
\hline
\end{tabular}

Source: Same as Table 2.1.

\subsection{The Deadlock in the Case of Tamil Nadu}

In Tamil Nadu, domestic work was included under the list of scheduled employment under the Minimum Wages Act, 1948 in 2007. Subsequently, a special tripartite committee was constituted under the convenership of woman Assistant Labour Commissioner in December 2009 to study the sector and give recommendations on wages and other provisions. Apart from some of the representatives from the central unions, unions of domestic workers were also part of the Committee. The Committee went to 6 zones in the state and met trade unions and domestic workers and NGOs working among domestic workers. Unions also had differences on the method of wage fixation; while some argued for taskbased differences in time rates, others argued for uniform wages across all tasks. There were debates on these issues in the meetings and one major demand was to include provisions for DA. The committee gave the report to the government suggesting a daily wage rate of Rs. 30 per hour across all tasks. However, no VDA was suggested. The committee also suggested for weekly rest days. However, the rates were not notified, though there were media reports ${ }^{27}$ on the proposed wage rates, quoting the then Minister of Labour.

Two divergent views exist on reasons for the withdrawal of the State from completing the MW fixing process. As per organizations/unions of domestic workers, since state elections were approaching at that time the government kept the recommendation in abeyance as it was thought the announcement would disturb middle class interest an middle class interest and thus affect their election prospects. The change of government after election affected the prospects of minimum wage fixation and many unions/organizations shared their anxiety about the disinterest among the current leadership on the issue. Unions have given many representations to the labour department and the Minister and Chief

${ }^{27}$ Tamil Nadu Annexure (a) \& (b).

Conditions of Work and Employment Series No. 66 
Minister on the issue but there have been no positive response. Many shared the indifference of the present government in passing the minimum wage notification. ${ }^{28}$ Unions also shared the reservation and reluctance of concerned officials in notifying minimum wages as they are also employers.

On the other hand a group of activists and officials attribute the rolling back of the previous government to the debates and differences among the unions and thus the lack of any consensus. However, all major unions have opposed this and argued that there was consensus on the issue. It was shared that Rs. 50 was the proposed daily wages suggested by them per hour across all tasks and there were no difference among unions on this. Further all the unions expressed their willingness to accept any wage rate to start the process of recognizing domestic workers.

\subsection{Working Hours, Over Time, Rest Days and Other Provisions}

If any employee whose minimum wage is fixed under the Act works on any day in excess of the number of hours constituting a normal working day, the employer is required to pay him for excess hours at the overtime rate fixed under this Act or under any law of the appropriate Government for the time being in force, whichever is higher. ${ }^{29}$ Further the Act specifies that in regard to any scheduled employment, the appropriate Government may: (a) fix the number of hours of work which shall constitute a normal working day, inclusive of one or more specified intervals; (b) provide for a day of rest in every period of seven days; (c) provide for payment for work on a day of rest at a rate not less than the overtime rate. ${ }^{30}$

All the notifications on minimum wages, specifically or otherwise, define or assume normal working hours in a day as a maximum of 8 hours. Rajasthan and Kerala explicitly mention 8 hours as the normal working day while other states which set the rates for 8 hours schedule assume an 8 -hour day. As has been discussed earlier, in the context of a growing number of live-in workers who constitute for about 10-20 per cent of domestic workers, ${ }^{31}$ the assumption of 8-hour normal working day for domestic workers shows how alien are the interventions from the realities of the sector.

\footnotetext{
${ }^{28}$ The present Minister of Labour (as per one of the organizers) questioned in a meeting the very need to notify minimum wages suggesting that domestic workers are already getting more than what they deserve and require.

${ }^{29}$ Convention No. 189 requires members to "take measures towards ensuring equal treatment between domestic workers and workers generally" in relation to normal hours of work, overtime compensation, periods of daily and weekly rest, and annual paid leave (Art. $10(1))$.

${ }^{30}$ The Hours of Work (Industry) ILO Convention 1919 (No.1), sets 48 hours a week as the acceptable limit for a normal working week. The Forty Four Hour Convention, 1935 introduced a new limit, which is now the ILOs vision of acceptable working hours.

${ }^{31}$ There are no accurate estimates of their number as they mostly go unaccounted since they stay with their employers. 
Table 2.6. Comparison of working hours - State wise

\begin{tabular}{|l|l|}
\hline States & Working hours \\
\hline Karnataka & Limit fixed at 8 hours \\
\hline Andhra Pradesh & No limit defined, assumption of 8 hours \\
\hline Bihar & No limit defined, assumption of 8 hours \\
\hline Rajasthan & Fixed at 8 hours \\
\hline Kerala & No limit defined, assumption of 8 hours \\
\hline
\end{tabular}

Source: Same as Table 2.1.

However, in the case of part time workers who have multiple employers, the worker will always be working for each employer for less than the stipulated normal working time of 8 hours. When the working hours in all various houses are put together, she may be working for more than 8 hours. Since the choice of number of employer-households and working hours is an individual decision, regulating the working time of part-time workers is an issue. The only way to prevent the worker from working above normal hours is to ensure adequate income which could be achieved through better hourly wage rates.

None of the notifications makes any provision for any rest period and assumes the worker to work continuously. None sets a maximum limit to permissible overtime hours. Further, except Karnataka and Rajasthan, there is no mention of overtime wages. Even in states where overtime wages are specified, the calculation of overtime and its payment is an issue in the context of part-time worker who works in different houses.

Overtime wages are payable if the worker is made to work for more than 8 hours. But in the case of part-time workers who have multiple employers, the worker may be made to work for additional hours above the contract time by any particular employer or many employers which may extend her normal working day beyond 8 hours. A normal practice prevalent in the employment of part-time domestic workers, which clearly came out in the discussions with domestic workers and their organisations, was the practice of assigning more tasks than what was agreed upon in the initial contract. These tasks are not well defined and could vary from cutting vegetables, folding clothes, shopping to washing the child and supervising the child etc., which could eventually extend a worker's hours of work in a particular household. Further, on days when there is extra work on account of guests, functions, festivals etc. the amount of work would vary and hence the time worked would increase. A worker's working hours could thus be extended even just by doing extra work in a particular household. Whether she is eligible for overtime is an issue that is open for debate. One could identify the employer responsible for causing overtime work, but the way overtime wages are understood in the Act is not of any help. Since domestic work arrangements are different from other sectors of informal employment some of these issues need further analysis. 
Compulsory rest day or weekly off is least in practice although the minimum wage for all states clearly specifies the number of working days as 26 per month, and some states clearly provide for four days compulsory weekly offs/rest days in a month in the notes ${ }^{32}$. A comparative analysis is provided in Table 2.7 .

Table 2.7. Comparison of over time and rest day - State wise

\begin{tabular}{|l|l|l|}
\hline States & $\begin{array}{l}\text { Status of over time payment above } \\
\mathbf{8} \text { hours }\end{array}$ & Rest day \\
\hline Karnataka & $\begin{array}{l}\text { Over time wages are double above 8 } \\
\text { hours }\end{array}$ & $\begin{array}{l}\text { Mention about rest day indirectly with fixing working } \\
\text { days per month as 26 days }\end{array}$ \\
\hline Andhra Pradesh & No mention about over time payment & $\begin{array}{l}\text { Mention about rest day indirectly with fixing working } \\
\text { days per month as 26 days }\end{array}$ \\
\hline Bihar & No mention about over time payment & $\begin{array}{l}\text { Direct mention about rest day - 1 day weekly off; over } \\
\text { time wage payment if made to work on weekly day offs }\end{array}$ \\
\hline Rajasthan & $\begin{array}{l}\text { Overtime wages are double above 8 } \\
\text { hours }\end{array}$ & $\begin{array}{l}\text { Mention about rest day indirectly with fixing working } \\
\text { days per month as 26 days }\end{array}$ \\
\hline Kerala & No mention about over time payment & $\begin{array}{l}\text { Direct mention about rest day - 1 day weekly off; over } \\
\text { time wage payment if made to work on weekly day offs }\end{array}$ \\
\hline
\end{tabular}

Source: Same as Table 2.1.

Though rest days are provided in all the notifications, there is no mention about payment if a worker is made to work on rest days in most of the states with exception of Bihar and Kerala. During interaction with organisations of domestic workers and workers, the absence of a weekly rest day was the most often highlighted issue for which the notification provides for but only partially by not providing for any penalisation of employers.

As regards other provisions, there are many differences across states in some of the details of the notification. Andhra Pradesh and Bihar categorically prohibit discrimination on the basis of sex. ${ }^{33}$ Minimum wages are always fixed in terms of cash, which makes the employer liable to pay wages in cash. In the context of domestic workers, because of the specificity of the workplace and personal relations governing their employment, payment in kind is an issue. ${ }^{34}$ However, it is only in Bihar that makes it categorical on payment of wages in cash. ${ }^{35}$

${ }^{32}$ ILO convention of domestic work (C.189) specify the weekly minimum rest period as 24 consecutive hours.

${ }^{33}$ ILO convention on domestic work (C.189) directs members to establish remuneration for domestic workers without discrimination based on sex (Art. 11). This non-discrimination clause aims to address undervaluation and underpayment of domestic work resulting from discrimination based on sex, as envisaged in the Equal Remuneration Convention, 1951 (No. 100).

${ }^{34}$ As regards the modalities for the payment of remuneration, the Convention (C.189) provides that payments shall be made: (a) directly to the domestic worker; (b) in cash; and (c) at regular intervals but at least once a month (Art. 12(1)).

${ }^{35}$ Convention 189 establishes that national law, regulations, collective agreements or arbitration awards may allow the payment of a limited proportion of the remuneration in the form of payments in kind. The monetary value attributed to such payments in kind must be fair and reasonable (Art. 12(2)). 
Table 2.8. Comparison of other provisions - State wise

\begin{tabular}{|c|c|c|c|}
\hline States & Discrimination on the basis of sex & Cash payment & Food and non cash benefits \\
\hline Karnataka & $\begin{array}{l}\text { No specific mention on } \\
\text { discrimination on the basis of sex }\end{array}$ & $\begin{array}{l}\text { No specific mention about } \\
\text { payment of minimum wages in } \\
\text { cash }\end{array}$ & $\begin{array}{l}\text { No mention about food or other } \\
\text { non cash benefits }\end{array}$ \\
\hline $\begin{array}{l}\text { Andhra } \\
\text { Pradesh }\end{array}$ & $\begin{array}{l}\text { Specific mention - no } \\
\text { discrimination on the basis of sex }\end{array}$ & $\begin{array}{l}\text { Specific mention about payment } \\
\text { of minimum wages in cash }\end{array}$ & $\begin{array}{l}\text { No mention about food or other } \\
\text { non cash benefits }\end{array}$ \\
\hline Bihar & $\begin{array}{l}\text { Specific mention - no } \\
\text { discrimination on the basis of sex }\end{array}$ & $\begin{array}{l}\text { No specific mention about } \\
\text { payment of minimum wages in } \\
\text { cash }\end{array}$ & $\begin{array}{l}\text { No mention about food or other } \\
\text { non cash benefits }\end{array}$ \\
\hline Rajasthan & $\begin{array}{l}\text { No specific mention on } \\
\text { discrimination on the basis of sex }\end{array}$ & $\begin{array}{l}\text { No specific mention about } \\
\text { payment of minimum wages in } \\
\text { cash }\end{array}$ & $\begin{array}{l}\text { No mention about food or other } \\
\text { non cash benefits }\end{array}$ \\
\hline Kerala & $\begin{array}{l}\text { No specific mention on } \\
\text { discrimination on the basis of sex }\end{array}$ & $\begin{array}{l}\text { No specific mention about } \\
\text { payment of minimum wages in } \\
\text { cash }\end{array}$ & $\begin{array}{l}1 \text { hour } 1 \text { meal; } 4+\text { hours } 2 \text { meals; } \\
\text { live-in workers all } 3 \text { meals with no } \\
\text { cost }\end{array}$ \\
\hline
\end{tabular}

Source: Same as Table 2.1.

The Kerala notification provides for free meal, number of such meals depending upon the duration of work. Thus, live-in workers are entitled to all 3 meals with no cost, while a part-time worker working for an hour is also entitled for one meal. In all the states, prohibition of children from domestic work is specified with the age of the child defined as 14 years and below in all states except Kerala (18 years and below). ${ }^{36}$ Interestingly, largely owing to female dominance in the sector perhaps, the Kerala notification also mentions about the employers responsibility to ensure safety of women workers in the workplace.

Another specificity of domestic work is that multiple tasks are done by the same worker on the same day for varying durations of time. To account for such multiple tasks, the Minimum Wage Act 1948 provides for wages for two or more classes of work (under Section 16). Under the provision, if an employee does two or more classes of work, to each of which a different rate of wages is applicable, the employer is required to pay to such employee in respect of the time respectively occupied in each such class of work, wages at not less than the minimum rate in force in respect of each such class. In states (Karnataka and Kerala) where the tasks and rates are differentiated, there has been no provision in accordance with this section that ensures workers the eligible minimum wage.

Apart from these provisions on working conditions, the notifications on minimum wages in the states of Karnataka and Andhra Pradesh also specify conditions with regard to the enforcement of the Act. As per the Act, as it is applicable to other sectors, every employer is required to maintain registers and records giving particulars of employees, the work performed by them, the wages paid to them, the receipts given by them and any other required particulars. Further, to ensure compliance of the Act, labour inspectors are appointed who conduct regular inspections. In both states however the notification

\footnotetext{
36 This has a definitional ambiguity as the national law on child labour, Child Labour (Regulation and Prohibition) Act, 1986, defines child labour as those who are 14 and below.
} 
exempts the employer from keeping records/wage slips etc. as well restricts inspection. The details of these and their implications are discussed in the subsequent chapters.

\subsection{Revision of Minimum Wages}

Under the Act, The Government has to review the minimum rates of wages and revise the minimum rates at intervals not exceeding five years. As with initial fixation two methods have been provided for revision of minimum wages - the Committee Method and Notification method. Except in the state of Kerala where the wage rates were fixed only in 2010, wages have already been revised in the four states. In Karnataka though the revision was due in 2009, the revision happened only in April 2011, two years later after the 5 year period suggested under the Act for revision. The delay in the revision was attributed by the officials to the time taking exercise of consultation that preceded the revision as there have been many criticisms on the earlier notification. The preliminary notification was issued in April 2010 and as per the final notification no comments for revision was received on the draft (Karntaka Annexure- 2). This official version however is contested by the unions/organizations. The Minimum Wage Advisory Committee as in the past round included a representative of KDWU as a special invitee, and as per this representative the union demanded for a 25 percent increase in wages, to which there was a general opposition, even from other trade unions. ${ }^{37}$ Contrary to this, the minutes of the meeting of the committee recorded 'unanimity' of all members regarding the rates. Following the procedural formalities the revised wage rates were notified in 2011 cancelling all previous notifications. In the revised notification, different categories and durations of work and revised terms were notified.

Table 2.9. Karnataka: Minimum wage rates, 2004

\begin{tabular}{|l|l|l|}
\hline Class of employment & $\begin{array}{l}\text { Working hours of a worker } \\
\text { - Daily }\end{array}$ & Monthly Basic \\
\hline Washing the clothes / Washing the utensils & 45 minutes & 150 \\
\hline $\begin{array}{l}\text { Washing the clothes / Washing the utensils / Housekeeping (in a house } \\
\text { of 1,000 sq. ft) }\end{array}$ & 45 minutes & 150 \\
\hline $\begin{array}{l}\text { Washing the clothes / Washing the utensils / Housekeeping and looking } \\
\text { after the children }\end{array}$ & 8 hours & 1,600 \\
\hline $\begin{array}{l}\text { Washing the clothes / Washing the utensils / Housekeeping and looking } \\
\text { after the children / and taking them to school and back and other } \\
\text { miscellaneous domestic work }\end{array}$ & 8 hours & 1600 \\
\hline
\end{tabular}

Source: Government of Karnataka, G.O Notification No. KE 88 LMW 2004, dated 12-3-2004.

\footnotetext{
${ }^{37}$ Other union representatives were agreeable for only 5 per cent increase and they argued that the current wages was good and enough for the work that domestic workers undertook. 
The durations of work for which the minimum wage was fixed for a month are 45 minutes and 8 hours. In the detailed notes that follow the rates (see Annexure 1) the notification also specifies the rates for one hour as Rs. 299 per month for washing clothes/washing utensils/housekeeping and other miscellaneous domestic work which are not specified in the schedule.

Thus, when one compares the old rates with the revised minimum wage rates of 2011 , there is a shift from monthly wage rates to daily wage rates. The revised notification fixes daily rates for 8 hours work. Thus the revised wage does not provide for hourly or short duration employment, suggesting for a calculation of wages for shorter durations based on the daily wage rates. Thus, though the revised notification is definitely an improvement over the earlier poor wage rate, the union argues that it ignores the specificity of part time domestic work, and adversely affect the wages of workers who work for small duration, though the intensity of work is higher in these cases. For example if a worker works for 8 hours for a single employer performing cleaning tasks, the monthly minimum wage would be Rs. 4967. A part time worker employed with 4 houses, 2 hours each for same tasks will also fetch same wages. But in the latter case, the intensification of work and complexities in meeting the demands of multiple employers are high. Besides this, considerable time, efforts and resources are required to commute between work places.

Further, in the revised notification there is no mention about house size unlike the earlier notification which defined the rates for a house of 1,000 sq.ft. The revised notification also amended the notes section by deleting the provision for family size - If family size exceeds 4 members, 10 per cent additional wages with VDA should be paid over and above the rates specified in the schedule (Karnataka Annexure 1).

In Bihar, as discussed above VDA was not given to domestic workers till 2009. In 2009, wages were revised to include VDA, which increased the monthly wage rates from 244 for an hour to Rs. 337 and for 8 hours from Rs. 1950 to Rs. 2691. However, immediately after this revision, the minimum wage for domestic work was revised again in 2010 as per GOI letter to all states directing states not to fix wages below the national daily floor wage of Rs. 122. Accordingly, domestic workers' wages were revised in 2010 but with effect from 2009, which would enable domestic workers demanding for retrospective wages. The revised wages was notified in March 2010- the basic wage was increased by 15 per cent taking the monthly wages for an hour to Rs. 430 and 8 hour wages to Rs. 3433 . There has been no consultation with any of the stake holders in these revisions and was done purely as an administrative exercise, which was clear from the interviews with unions and discussions with labour officials.

In Rajasthan, the rates were revised in May 2012. Apart from the increase in rates there has not been any change in the categories or duration for which wages was fixed. The basic monthly wage rate per hour more than doubled from Rs. 264 in 2007 to Rs. 543 in 2012. The revision followed the notification 
method with a preliminary notification and final notification. Rajasthan Mahila Kamgar Union, the union of domestic workers in the state was actively involved in the revision of wage rates. The union had given several representations to the labour department demanding revision in minimum wages and also including domestic work under the category of skilled work.

In Andhra Pradesh, VDA was not included in the calculation of minimum wages for domestic work. In 2010 a decision was taken to include VDA and also to revise minimum wages. Notification method was followed and the rates were revised in January 2012 though the preliminary notification on the revision was published in December 2010. Here again there has been no change in any other details of the notification except that of basic wages - basic monthly wages for daily $1 / 2$ hour work was increased from Rs. 163 to Rs 284; for one hour from Rs. 325 to Rs. 565; for 11/2 hours from Rs. 488 to Rs. 848; for 8 hours from Rs. 2600 to Rs 4521 . Here again there has been some consultation with organisations working among domestic workers but not to the tune that the organisations felt that their concerns were taken into account such as separate rates for rural and urban areas and so on.

On the whole, the revision of minimum wages across states saw an improvement in rates and in many cases a substantial one. Dearness allowance also became part of wage revisions in all the states protecting the workers from price increases. The tasks and duration of work under the notification remained the same in Rajasthan, Bihar and Andhra Pradesh even with revisions. These states followed a fairly simple method of classification of tasks and duration, which to some extent explains its continuation. However, in Karnataka which started with an elaborate method, the revision simplified the task divisions and duration, clearly pointing to the need to keep the minimum wages rate notification simple and easy to comprehend. In all the states where revisions happened, except for Bihar, consultations with unions or organisations working among domestic workers were held during revisions and their engagement in the deliberations is visible - in terms of better wages rates. In Rajasthan, while unions were not active at all during the first wage fixation exercise, they played a central role in the revision.

\subsection{Adequacy of the Notified Minimum Wages}

Discussions were held with workers and union/organisation members on the adequacy of the amount fixed under the Act for having a minimum standard of living. Except in Bihar and Rajasthan, workers in general, when informed about the amount fixed under the Act, pointed out the inadequacy of the prescribed wages to make a living in the city. Most workers in all the states except Kerala are migrants and many did not own any house. Thus, many had to pay in a month about Rs. 1000 as rent and in Bangalore the rent was reported to be about as high as Rs. 1500-2000. Further, based on the interactions with the workers as well as organisations it was evident that 75-80 percent of domestic workers are single bread winners. Husbands were either unemployed or, according to them, incapacitated due to 
alcohol abuse, which results in women taking all the responsibilities of running the house. There were also many women who were separated and were running the house singlehandedly. In the southern states, a considerable section of the domestic workers were in the age group of 40-50, though there are also a good number of young girls 14 years old and older. Many girls either helped their mother with their paid work or did some part time paid work before and after schooling. There are many old women also in the occupation except in Rajasthan. Since old workers cannot manage to work for many households, their incomes are lower and hence they were living in deplorable condition. As per the Coordinator of Stree Jagruti Samiti, Bangalore, Karnataka, two-thirds of domestic workers have taken loans at exorbitant rates from local money lenders to meet contingencies. Food price increase and general inflation was raised in all the discussions with workers and unions which put increased pressure on the workers. Rises in expenditure on children's education and health was also pointed out. Children and workers themselves were reported to fall sick often - largely due to their poor living conditions and absence of balanced, timely food. Some workers also incurred money in transport as well. In Bangalore, workers who earned Rs. 5000-6000 a month reported that they found it difficult to manage their expenditures with overall price increases and many shared that they had to effectively cut on food expenditures.

Given the above, it was found that, the minimum wages of none of the states was sufficient to meet the basic needs of the workers. This was true even when one assume that the workers could work for 8 hours a day performing tasks that pay them the maximum. The highest minimum wage for domestic work per month is in the state of Karnataka; Rs. 5117 (Rs. 170.58 x 30). On average, a domestic worker works for 4-5 hours, performing 3-4 tasks as it is rarely feasible for a domestic worker to work 8 hours per day because of the other duties on her as wife and mother. Assuming 5 houses with 3 cleaning tasks, which is usually taken as 1 hour work by the employer (though the actual time exceeds this time with additional work) and paid at the minimum wage this would mean a monthly earning of Rs. 3583 in Bangalore, Rs. 3260 in Hyderabad and Rs. 3133 in Jaipur; Rs. 2712 in Patna and Rs. 3938 in Kerala. If workers who could manage to earn Rs. 5000-6000 are not able to meet their basic needs, then with the statutory floor wage acquiring a minimum standard of living is unrealistic. As per an estimate, in 2011, if the poverty lines allowing nutrition norms of 2,200 or 2,100 calories in the rural or urban areas are to be met, at least Rs.1,085 a month (Rs.36 a day) and Rs.1,800 a month (Rs.60 a day) are required respectively (Patnaik, 2011). ${ }^{38}$ Since each full-time worker needs to support nearly two dependents, these correspond to a minimum daily wage of Rs.108 and Rs.180 respectively. But even this is an underestimation as no margin exists for medical emergencies, life cycle ceremonies, or old age. Thus, while the notification gives domestic workers the official status of a worker within a legal framework,

\footnotetext{
${ }^{38}$ In India estimation of poverty is highly debated with the Planning Commission, the official agency quoting an abysmally low figures - that a person is considered 'poor' only if his or her monthly spending is below Rs.781 (Rs.26 a day) in the rural areas and Rs.965 (Rs.32 a day) in the urban areas. This has been widely opposed by various stake holders. For a detailed discussion see Patnaik (2012).
} 
the actual wage fixed is apparently far from adequate to meet the needs of domestic workers and their family. In this context, maintenance of a basic standard of living requires at least one other member of the household to be employed, with same or better salary package.

On the whole the processes in the states studied are characterized by ambiguities in procedure and norms in fixing minimum wage. The definition of domestic work followed in the minimum wage notification is task based in all states though the actual task divisions differ across the states. Near absence of wider consultations with workers and employers is yet another aspect. Unions and organisations working among domestic workers are only minimally involved in the processes. Minimum level of deliberations characterizes the wage board meetings on wage levels and other related conditions of work. In general, there is a lack of clarity on the criteria and basis for setting minimum wage for domestic work. All these aspects suggest the desirability of having inclusive debates involving workers, employers and all other relevant stakeholders while fixing and revising minimum wages. 


\section{Chapter 3. Awareness on minimum wages}

During the data collection, special attention was given to understand the level of awareness of various stakeholders (workers, employers, trade unions/domestic workers organisations and the government functionaries) on the existence as well as the provisions therein in the Minimum Wages Act, 1948. This exercise was meant to capture the conceptual and practical gaps in its application and to relate the linkages between the awareness/orientation levels of major stakeholders on the acceptance of minimum wage norms and it compliance.

\subsection{Awareness on Minimum Wages - Workers}

Awareness among the workers on the existence and provision of the Minimum Wages Act 1948 and the prescribed minimum wages in force in the respective state is equally pertinent for effective implementation. This is especially true in the context of domestic workers as there is a curb on inspections either direct or tacit, which makes complaints as the only system of enforcement. To understand the level of awareness on minimum wages and its provisions, a sample of 30 workers each were surveyed in all the selected states. Workers in all the states in general were unaware of the existence of minimum wages. Even those who were aware of the Act, were not clear about the provisions of it with none of these workers knowing all the provisions. Workers who are part of the organised initiatives were better off with basic knowledge of the existence of legal intervention and some with a rough understanding on the rates. But even these favourably placed workers did not know the actual rates. The survey results reveal that of the 150 sample workers only 17 per cent $^{39}$ were aware of their right to minimum wages, while the rest reported ignorance about the coverage of the law. It is quite likely that this proportion will be much lesser in the rural areas and smaller towns.

Table: 3.1. Workers awareness on minimum wages - State wise (number of persons)

\begin{tabular}{|l|l|l|}
\hline States & $\begin{array}{l}\text { Awareness of the extension of MW Act, } \\
\mathbf{1 9 4 8} \text { to domestic work }\end{array}$ & $\begin{array}{l}\text { Awareness about main } \\
\text { provisions }\end{array}$ \\
\hline Karnataka & 6 & 2 \\
\hline Andhra Pradesh & 4 & 1 \\
\hline Bihar & 1 & 0 \\
\hline Rajasthan & 2 & 1 \\
\hline Kerala & 13 & 4 \\
\hline
\end{tabular}

Source: Survey data, 2012

\footnotetext{
${ }^{39}$ These proportions are likely to be over projections as the survey was carried out in a short period and was limited to one or two areas in the heart of the city. Further, the survey was carried out with the help of the unions and hence it is likely to be over represented by workers who are part of the unions or familiar with the union activities. 
However, even these workers when asked in detail about the current minimum wages and other provisions were not in a position to elaborate. Though unions have given workers associated with them pamphlets and notices on the wage rates fixed, since a large number of them were illiterate, they could not read it or even if they did, could not recollect the rates. Thus, only five workers across the states surveyed which had held discussions knew the present minimum wage rates. Many workers also expressed complete ignorance on the right to a minimum number of rest days. This was known to all those who were associated with some workers organisation/trade unions; still there was confusion about the exact provisions. As regards other conditions of work there was absolute ignorance among workers as none of the respondents reported any understanding on these.

Leave and wages rates were seen as matters of negotiation by all in these states. However, the level of awareness varied across states with Kerala showing the highest and Bihar and Rajasthan showing the least. In Kerala about 43 per cent of those who were surveyed had heard about minimum wages for domestic work. However, many did not know the actual rates and the details of weekly rest days and other provisions. The main source of information for those who were members of organisations was from pamphlets and notices of their organisations, while for those outside these were newspaper reports. In Karnataka the awareness on minimum wages was limited to about 20 per cent of the surveyed workers, with only 2 workers knowing the exact details. In Andhra Pradesh, about 13 per cent reported of knowledge of the legislation while only 1 person could give the correct wage. In contrast in Rajasthan (except two respondents) and Bihar (except one) most of the respondents did not know about the legislation, with an abysmally low level of awareness.

In Bihar, it was reported by one person from the union that workers who were aware of statutory provisions in some pockets of intervention were also not in a position to negotiate wages due to the fear of job loss. To quote an organizer, "It will take a long time between the knowledge and demanding of minimum wage" (Interview with Mr. Narayan Purbey, General Secretary, AITUC, (Garelu Kamkar Sangatan), Bihar)

Workers' acceptance of domestic work as separate category vis-à-vis from wage work was also found during discussions with workers and unions. Many workers, especially in Bihar and Rajasthan still could not conceive that their work was comparable or equivalent to other informal sector work. In Bihar interestingly, a group of workers who are not active in the union expressed their initial inability in bringing in terms with considering their work as any other paid employment. The feudal framework and caste based segmentation of tasks are strong in both these states which could be the reason behind the lower status of domestic work. In general, it was found that domestic workers did not consider themselves eligible for the welfare schemes which may be applicable to them as workers. In the limited interactions with workers in many states, it was clear that even for those who were part of the 
unions/workers organisations did not understand the real meaning of a worker or a union or the positioning of their unions vis-à-vis other worker collectives.

\subsection{Awareness on Minimum Wages - Employers}

It is generally known that the employers are better versed with the provisions of various labour laws as they are usually better educated. In order to know the extent of awareness among employers about the provisions of the Act, a small survey of 10 employers were carried out in all the states covered in the study. Interestingly a considerable proportion of employers were aware of the existence of minimum wage legislation though many did not have a clear understanding on the exact details of the Act. The results reveal that of the 50 sample employers, 27 (54 per cent) reported awareness about the coverage of domestic work under the Minimum Wages Act,1948. Here it needs to be noted that the survey was conducted only in the cities where the level of awareness could be relatively better. The figure could be much less if one takes into account small towns and rural areas - this was pointed out by many organisations/unions. However, there have been differences across states with the lowest awareness among employers in Rajasthan and Bihar and the highest among employers in Karnataka, followed by Andhra Pradesh and Kerala. The comparatively higher level of awareness in Karnataka could also be due to the existence of the Act for a number of years in the state. The active engagement of unions/organisations in the public sphere such as holding dharnas, demonstrations could also a factor that has spread awareness on the issues. However, out of those reported awareness about the minimum wages, only 35 percent knew the prevailing rate. Here again, the proportion was highest in Karnataka. Those employers who did not know the actual minimum wages said the wages that they were giving the workers were more than statutory wages and hence they do not have to know about it. Very few expressed awareness on leave provisions and none was aware of over-time wages (wherever it is applicable) - and these are the most violated provisions of the Act across all the states. Awareness on leave provision was highest in Kerala, and many employers considered leave as the right of the workers. This could be attributed to the larger political history of the state with workers' rights occupying a central position in the social discourse. In other states, even in cases when domestic workers were given leave, employers considered leave as a matter of negotiation and favour and not as the right of workers guaranteed under the Act. However, the employers were largely unaware of other provisions under the Act. As regards the maintenance of records, notices, extracts, annual returns etc. there has been a complete ignorance in these states where the law does not exempt employers. Even in other states the employers were unaware of the exemption.

Media reports, newspapers and TV, were cited as the main sources of information on minimum wages. Many expressed ambiguity in the information shared in media as they never gave complete information. The division of tasks and short duration aspect of part time work was highlighted as issues adding to the ambiguity of the rates. Employers complained of the lack of efforts by the labour department to 
publicise the main provisions of the notification and the rates whenever revised. On the issue of keeping records of workers, though there has been an overall reluctance, many employers expressed willingness to do so. Thus, of the 50 employers surveyed, 38 percent were willing to keep records as many thought this would help to professionalize the system. In fact, few employers already had a record of wages and leave - as a measure of accounting for borrowing and cutting wages for days of absence from work.

\subsection{Awareness on Minimum Wages- Domestic Workers' Organisations / Trade Unions}

Unionisation is an important way that workers fight for their rights and their implementation. The role of unions is important not only in demanding for legal interventions but also for the enforcement of these - even informally. The approach taken by some of the organisations of domestic workers are found to be different in this context. All the union members and organisations were aware of the legislation and wage rate fixed under the act. But, since the wages were revised every 6 months or at least once in a year with changed dearness allowance, it takes a few months even for organisations who are actively engaged in the issue to get themselves familiarised with the present rates. Many organisations, as they did not have any day to day interaction with the labour department, reported getting the information on the increased D.A only after many months as there has been no proper communication from the labour department.

On the other hand, some of the unions were found not taking any active role in getting themselves acquainted with the new wage rates as the rates in any case was fixed at a low rate and many workers were already getting a higher wage rate. Organisations also complained of the lack of any effort on the part of the labour department to disseminate and publicise the wage rates. Even to get any basic notification it was reported that they often have to visit the labour department many times as the issues of domestic workers never occupied any priority to the department. The lack of experience of most of the organisations that are active among domestic workers, on the procedural process and practices of labour law legislation and its enforcement adds to the ambiguity.

None of the organisations had a fuller understanding of the legislation. Many of the organisations were aware of the wage rates and leave provisions. They were largely ignorant about other provisions. Even in states where there has been a long history of active organisations of domestic workers such as Karnataka and Andhra Pradesh none of the organisations were aware of the provisions in the notification on exclusion of employers from record keeping and restricting inspection. These critical points though were occasionally raised in the context of specific cases that were never seen as issues related to the notification of minimum wages. In Kerala, these provisions were not part of the minimum wage notification but have come in the form of an executive order of the government. However, none of 
the organisations including Self Employed Women's Association (SEWA) knew about the order and the department has also kept this at a low profile.

However unions played an important role in spreading awareness among workers and employers on the legislation. Some organisations had regular interactions with workers on various issues in their localities. Apart from this, publicity materials such as pamphlets, brochures and notices are distributed among workers on minimum wages and welfare benefits in local languages. Street plays, skits and group songs were also used to spread awareness on the poor conditions of domestic work and the need to organise against their exploitation. Some organisations were found holding meetings involving the labour department occasionally to disseminate the recognized status of their employment and the related provisions. This was reported in all states except Bihar and Kerala. Further participation of workers in demonstrations, dharnas and protests are also found important is spreading information on wages and other welfare schemes. In all these awareness generation exercises, as evident in the pamphlets and other materials, the unions were found emphasising the welfare welfare/scheme component aspects more than the labour rights, such as the minimum wage, largely to attract workers to the union. The schemes in many cases were not purely employment related but related to the issues for survival in the cities such as housing, getting a ration card and so on. These are seen by the unions as important entry points to get workers into a common platform. Thus, the labour aspect of domestic work and the framework of workers' rights were found to be given a low profile by organisations/unions of domestic workers in general. It was evident from the interviews that even workers who were part of the organisations were ignorant of what unionisation/organisational affiliation really meant apart from their relation with the organisation either for accessing a welfare scheme or in the hope of getting some benefit.

\subsection{Awareness on Minimum Wages - Labour Officials}

All the labour officials covered in the survey claimed that the department had taken an active role in publicising the rates. In many states, wages are publicised in newspapers after revision in the local language. The organisations have pointed out that such publicity exercises are haphazard. Further, no worker, even when they are able to read knows that those are for them.

Concerned labour officials at the respective state headquarters were aware of the present rates and other conditions of work - though they were not fluent in the exact details of these. But many were not aware of the history of legislation and the details of the preliminary and previous orders though they knew the procedural practises in general. However, unions that were active outside the city jurisdiction complained of labour officers not being aware of even the minimum wage rates. Interestingly in one of the interaction workshops in one of the rural areas in Andhra Pradesh, the labour official quoted old figures of minimum wages though the same had been revised and there has been a substantial difference 
between the old rate and the new rate. Many organisers complained that labour department officials at the district level did not know about the revised wage - they themselves are not aware of many issues.

There was also confusion about other legal provisions for domestic workers in Andhra Pradesh. For instance, on the extension of Workmen's Compensation Act to domestic work there were contradictory opinions. Finally it was clarified (after discussing with the concerned division of the labour department) that though the preliminary notification was issued in 2009 , no final notification was issued on the extension of the Act to domestic workers.

Though the labour officials were aware of the rates, there has been a general lack of disinterest and apathy in the issues of domestic workers among a large number of officials with few exceptions. ${ }^{40}$ The officials in general shared the view that the minimum wage is not an issue for domestic workers as they are getting much higher wage rates and that they have strong bargaining power with the employers. Many even suggested through narrating personal experiences of how the employers are at the mercy of workers. They also reported that the number of theft cases involving domestic workers is on the rise, suggesting for some policy intervention to protect the interest of employers. On the provisions of exception on record keeping and restricting inspection, labour officials across all states wherever it is applicable expressed the importance of these provisions in protecting the privacy of households.

On the whole, poor knowledge about the existence of the minimum wage for domestic work exists in all the states among workers and employers. Even the organizations working among domestic workers were not clear about the details of the provisions, which results in the lack of specific interventions to address violations of the law.

${ }^{40}$ This was clearly evident in the interviews with the officials across states and also from discussions with workers and union leaders. 


\section{Chapter 4. Enforcement of minimum wages act}

All employers who employ one or more workers in any scheduled employment in respect of which the minimum wages have been fixed under the MWA 1948 are bound to pay statutory minimum wages. The respective State Governments are the appropriate authority for enforcing the labour laws in the scheduled tasks under domestic work. The Labour Commissioner of individual States is in-charge of the enforcement machinery. The Labour Commissioner is assisted by the Additional Labour Commissioner, Joint Labour Commissioner, Deputy Labour Commissioners, Assistant Labour Commissioners, Labour Officers and Inspectors for enforcement of various labour laws. The Labour Inspectors conduct regular inspections and in the event of detection of any case of non-payment or under-payment of minimum wages, they advise the employers to make payment of the shortfall in wages. In case of noncompliance, penal provisions prescribed in the Act are taken recourse to. ${ }^{41}$ Any employer who contravenes any provision of the Act is punishable with imprisonment for a term, which may extend to six months or with fine, which may extend to five hundred rupees or with both. The modes of enforcing minimum wages have been thus been confined to petitioning to the higher authorities and reasoning it out with them.

\subsection{Restriction on Inspection}

As discussed earlier, there are specific notes under the minimum wage notification that directly affects its enforcement. Every employer under the Minimum Wages Act, 1948 is required to maintain registers and records of workers giving particulars of employees, the work performed by them, the wages paid to them, the receipts given by them and any other required particulars. However, in three states (Karnataka, Andhra Pradesh and Kerala) ${ }^{42}$ the notification clearly specifies that employers are exempted from maintenance of registers and records. ${ }^{43}$ In two states (Bihar and Rajasthan), while there is no exemption of employers from record keeping in the context of domestic workers, there is a tacit appreciation of an exemption in the official understanding of the Act. Further as discussed earlier, no employer or worker is aware of this provision in these states and there has been no attempt to publicise the requirement which virtually fails the purpose of the provision.

\footnotetext{
${ }^{41}$ As per the Minimum Wages Act, Labour Commissioner or Commissioner for Workmen's Compensation or any officer not below the rank of Labour Commissioner or any other officer with experience as a judge of a civil court or as a Stipendiary Magistrate, are appointed to hear and decide for any specified area, all claims arising out of the payment of less than the minimum rates of wages as well as payment for days of rest or for work done.

${ }^{42}$ In Kerala, these provisions were not part of the minimum wage notification but were issued later in the form of an executive order.

${ }^{43}$ Karnataka Notification No. KAE 15 LMW 04, dated 12-03-04, Published in Gazette dated 13-04-04 (Annexure Karnataka1); Andhra Pradesh Gazette, extraordinary; G.O Ms. No 119, Labour, Employment Training and Factories, (Lab II, 10 December 2007) (Annexure AP -1(b)); Minutes of the Minimum wage advisory board meeting (Annexure Kerala-2).
} 
Yet another issue is the restriction of inspection in the context of domestic work. While labour inspectors are free to conduct inspections for any violations of the Minimum Wages Act, 1948 in general in the case of domestic work, restrictions exist in the states of Karnataka, Andhra Pradesh and Kerala. In Karnataka the notification states that "inspectors are prohibited from entry to any residential location; but the Commissioner of labour can direct any inspector to inspect any domestic premises under any of the labour Enactments and Rules there under". 44 In Andhra Pradesh too it is specified that "Inspector are prohibited from entry to any residential location. But the commissioner of labour can direct any inspector to inspect any domestic premises under any of the labour Enactments and Rules there under. ${ }^{45}$ In Kerala, though the notification does not restrict inspection, in the special order that followed the notification restricts inspection in accordance with the advice of the Minimum Wage Advisory Board which suggested that "Inspection could only be conducted if there are written complaints. Further no one below the rank of District Labour Officer (Enforcement) unless directed by the State Labour Commissioner could inspect houses and take any action", ${ }^{46}$ Thus in these states the notification itself did not provide for implementation mechanisms such as regular inspections and regulations for the maintenance of wage register by the employer. These provisions in the Act adversely affect the spirit of the legislation. Interestingly, in all the states where the unions were active and had been demanding for this legislation, the provision for exception from record keeping and restricting inspection existed. Definitely, this move is in anticipation of the possibility of unions demanding for inspections and strict enforcement of record keeping. In Rajasthan and Bihar, there are no restrictions on inspections and by law records are to be maintained. In these states the union/organisations were less active and fewer in number during the legislation, and hence the need for such a cover was probably not thought about.

During the field work, information was collected from Labour officials of various states on the number of inspections (if not restricted), complaints received, the process of grievance resolution and any difficulties in the enforcement of the Act and suggestions for effecting improvement in the compliance of various provisions of the Act. There has been no instance of suo motto inspections under the Act in the states of Bihar and Rajasthan where the same is not restricted. A common response of all labour officials was "Unless the domestic worker, NGO or organisation/union files a formal complaint, the Department is unable to look into the issues of domestic workers" (Interview with Mr. G Ajay, Joint Commissioner of Labour, Govt. of Andhra Pradesh, Hyderabad; Mr. Jinkalappa, Joint Labour Commissioner, Bangalore, Karnataka; Mr. Anil Kumar, Joint Labour Commissioner, Trivandrum, Kerala; Mr. C.B.S Rathore, Joint Labour Commissioner, Jaipur, Rajasthan). However, unions in

\footnotetext{
${ }^{44}$ Karnataka Notification No. KAE 15 LMW 04, dated 12-03-04, Published in Gazette dated 13-04-04; (Annexure Karnataka1)

${ }^{45}$ Andhra Pradesh Gazette, extraordinary ; G.O Ms. No 119, Labour, Employment Training and Factories, (Lab II, 10th December 2007) (Annexure AP -1(b)).

${ }^{46}$ Minutes of the Minimum wage advisory board meeting, (Annexure Kerala -2).
} 
Karnataka and Rajasthan complained that even in the event of a complaint, the labour department is reluctant to conduct inspections and the unions have to insist to carry out inspection.

In all the states, labour officials denied any complaints of violation of the Act that the department has received. As explained earlier, many officials were of the view that workers are getting more than minimum wages, though they acknowledged the absence of overtime wages in the context of live-in workers. Labour department officials shared few cases of child labour in domestic work which were taken up by the Department. However, this was countered by the members of various unions/organisations who highlighted the problem of poor reporting of violations of Minimum Wage Act, 1948 due to the poor socio -economic profile and characteristics of the workers. However, there have been few cases that the organisations have handled either through the labour department or at their own level. Ground realities coupled with the fact that there are many workers who do not get minimum wages suggest a weak enforcement mechanism.

\subsection{Constraints in Effective Enforcement}

The discussions with labour officials underline that the lack of awareness and collectivity among workers often lead to underreporting of violations of minimum wages. None of the officials in the state where the employers are exempted from keeping any records of domestic workers shared this as an issue. The restriction on inspection either apparent or tacit was also not highlighted by any of the labour official as an issue. However, the need to expand and augment the enforcement machinery was highlighted. The impossibility of the limited size of enforcement machinery to monitor and enforce a large number of labour laws (alongside minimum wages in a number of diverse sectors) was pointed out as an issue. To quote a response: "though formal and informal sectors are both in the purview of the Labour department, the size of the informal sector and its spread is certainly an issue in labour enforcement. In the context of domestic workers, the spread is at its maximum with workers dispersed across individual employer households" (Interview with Mr. Jinkalappa, Joint Labour Commissioner, Bangalore, Karnataka on $7^{\text {th }}$ August 2013).

The dispersion of the workplace in domestic work, being individual homes, and resultant inability of an inspection-based enforcement system to be organised was highlighted by many. Thus, it was felt that suo motto inspections are impractical administratively. Apart from the administrative difficulties of the current system of labour law enforcement in domestic work, the notion of households as private spaces and the reluctance to accept domestic work as any other informal sector employment was also embedded in many responses. The remark of one to the Labour Commissioner of Karnataka "Restriction on implementation is important component of the Act as one cannot disturb the privacy of households" (Mr. Gurudas Bhatt, Assistant Labour Commissioner, Bangalore, Karnataka interviewed on 7th August, 2012) itself reflects their overall approach. Further, the political will and the interest of 
higher authorities also counts as evident from the following response "With changes in the government and depending upon the understanding of the top bureaucracy there are shifts in the importance given to various labour laws and sectors. Domestic workers do not have voices and NGOS and unions among domestic workers are also few; neither are the sector of any interest to officials - this make their issues invisible" (Interview with Mr. C.B.S Rathore Joint Labour Commissioner, Jaipur, Rajasthan on $6^{\text {th }}$ October 2012).

The need to create awareness among employers and workers was highlighted by organisations and unions of domestic workers. The role of the labour department in this context was underlined as: "the Labour department is not taking a positive step; its involvement is limited to their attending the meetings which are organised by other organisations" (Interview with Sr. Lizzy Jose, Secretary, AP State Domestic Workers Union, Hyderabad on $3^{\text {rd }}$ November, 2012).

It was suggested by union members and workers that the prescribed/statutory wages in force should be given wide publicity through media, newspapers, etc. Apart from this it was also suggested to organise camps for workers under the aegis of the labour department through which awareness could be generated among workers who are largely illiterate and from low socio- economic backgrounds. In Andhra Pradesh, under the initiative of AP state domestic workers union such camps are organised through the Central Board of Workers Education and is reported to be effective. It was pointed out that, these camps have been an effective means of publicising the state recognition of domestic work as 'employment' and also creating awareness of the statutory wage rates and other provisions, because of the state tag that such programmes have. Since job security is one of the major issues that affect reporting of violation of minimum wages, some conditions for ensuring the job security of the workers reporting the cases of violation were suggested to be included in the Minimum Wages Act, 1948. Absence of any identity or records of employment was highlighted as the major issue. Though the same has been raised by some organisations in Karnataka and Andhra Pradesh it was not been taken up strongly anticipating resistances from various quarters.

In many cases of minimum wage violation it is frequently pointed out that the onus of proof of employment is on the workers, who then are left with no option but to leave the case. Lack of cooperation and sensitivity to the issues of domestic workers among the bureaucracy in general and the resultant tension and delay in getting justice was highlighted by the unions as one factor that prevent them from approaching the labour department. The bias towards employers who belong to the rich or middle income class and their influences or interference was also reported by the union members to affect the responses of the officials. However many organisations shared their experience with few supportive officials which made some changes in the overall environment of neglect.

The enforcement system can work efficiently only if the workers have the knowledge of the minimum wages fixed by the Government and also are aware of the extent to which they can approach the 
enforcement officers to seek protection. Workers were largely ignorant about any procedural mechanisms in the enforcement of the law even when they were part of the organisations/unions and thus knew about the existence of the law. Many workers were under the assumption that it was only the organisation/union that could be relied upon to seek any protection in case of any violation. These suggest the need to create awareness not only about the provisions of the Act but also on the enforcement mechanisms, let alone the possibility of making complaints and the details of the concerned officers. Awareness among employers is also suggested equally important. Pamphlets, brochures and notices circulated through workers are some of the methods through which organisations have tried involving employers. Some organisation has also issued appealing letters to employers which have made some change in the behaviour and attitudes of employers. Another issue in the context of enforcement is the lack of coordination among unions/organisations. Though there are some spurts of collective voices in the past many were found interested in individual gains and hence maintained distance from the rest. In fact, the entry of central trade unions into domestic work was widely criticised by many organisations who to some extent regarded this as a potential threat to their identities.

Given the poor number of workers represented through various organisations and the poor status of awareness on the provisions of the Act even among this limited number the enforcement of the Act is challenging. The only solutions to it are to create awareness about the provision under the Minimum Wages Act, 1948 and its enforcement mechanisms among the employers and employees and to promote unions/organisations of domestic workers. Inspection is an issue in all the states with the labour departments' rigid understanding of households as private spaces. But the fact is that they are public spaces as well - there is a need to strike a balance between privacy of households and workplace rights. Effective enforcement calls for in the words of an organiser " a carrot and stick approach- at the grass root level one has to create awareness - at the same time there is a need to have strict enforcement of the legislation" (Interview with Br. Varghese, Director, Montfort Social Institute, Hyderabad, Andhra Pradesh). 


\section{Chapter 5. Non-compliance: cases from the states}

In the course of data collection efforts were made to collate available case studies which directly or indirectly deal with instances of negation of minimum wages and related conditions of work. Cases of formal complaints ${ }^{47}$ from workers in general and specifically on poor wages or non-payment of wages or cut in wages was denied by all labour officials. The only cases that the labour officials shared were of child domestic workers- the employment of child domestic workers has been banned in the country since 2010. Though these cases were not directly of non-compliance of minimum wage regulation, in many cases to calculate the penalty, the minimum wage rate was referred to. Notwithstanding this, in the discussions with unions, organisations' working among domestic workers and workers it was clear that there have been cases of violation of the provisions of the Act. However, only few have been followed up or taken up with the labour department due to various reasons. ${ }^{48}$ The most important reason for not registering a formal case was the low awareness on the minimum wage law and its enforcement procedures. This combined with demand on time and financial pressure in registering and following up a formal case and the absence of any evidence of employment are also found to influence the poor registration of complaints.

Wages and other conditions are usually bargained at the individual level and in the context of non payment or poor payment the common strategy is to leave the employer. Informal mechanisms of setting minimum employment condition came out in the discussion with the unions in Rajasthan and Karnataka. In Jaipur, it was reported that "There is unity among workers - they do not agree to work below a particular wage. On wage increases also they decide informally. All workers ask for revised wages. There are few instances when all the workers have boycotted a particular house - an employer because of poor employment conditions. However, none of them were aware of minimum wages" (interview with Malathi Verman, a domestic worker and an active member of AITUC, Jaipur on $4^{\text {th }}$ October, 2012).

From all the states covered (except Kerala) ${ }^{49}$ in the study some cases of violations and ways of negotiations/confrontation was recorded. In the absence of the possibility of contacting the victims/direct parties these cases are documented on the basis of testimonies of other concerned parties (mostly organisers and fellow workers) and available newspaper clippings.

\footnotetext{
${ }^{47}$ All the unions mentioned about a number of cases of theft where workers are falsely implicated.

${ }^{48}$ There have been a small number of cases of child labour that the organisations/unions have handled with the support of the labour department in Karnataka, Rajasthan and Andhra Pradesh.

${ }^{49}$ One instance of non payment of wage for rest days was reported from Kerala also. In this case, a team from the workers union negotiated the matter with the employer who initially threatened them with termination of the worker from the job. However, with mounting pressure from the union the employer finally had to settle the wage and reinstated the worker.
} 
However, in the discussions with union members and organisers a number of cases were reported where the union had intervened. Most organisations were found demanding compensation packages when such cases came to them. These deals in most cases put the worker at a loss. According to the unions, given the living conditions of workers it is difficult to convince them for a formal complaint. The attraction of immediate cash income, often forces the workers to agree to poor settlements and the employers also use this to their advantage. Absence of formal records is the biggest challenge that the workers face in the context of any grievance redressal. No records are kept by employers even in states where there are no exemptions. Many unions now insist that workers maintain their own records which could be of some use in the future in the event of violations. In this context, mandatory registration of domestic workers is suggested as an effective solution by the trade unions/ organisations to implement the provisions as it provides the necessary proof required while resorting to possible means of redress.

\subsection{Cases from Andhra Pradesh}

There have been a few cases of complaints by domestic workers that the unions or organisations for domestic workers have taken up. While these are not purely wage oriented, they have been linked to the issue of wages indirectly. The details of these cases were collected from the unions or organizations of workers. ${ }^{50}$ These cases were not taken up with labour department though in the first case a complaint was registered with the labour department as per the union. The cases are based on the interviews with unions/organisations office bearers. ${ }^{51}$

Case 5.1.1. Meenakshi from Hyderabad (case reported in 2010) - At the time, Meenakshi was 45 years and was working as full time live-in worker. Her husband had deserted her and the sons were studying. To save money to educate them she took up full time work and her sons were put in hostels. In the particular house she worked for 1.5 years. She was paid Rs. 3000 a month. Two months wages were pending. She was accused of theft of a gold chain and was arrested by the police. As per the union the police physically tortured her and subsequently she was released. The union was approached and a petition was filed with the State Human Rights Commission. Afterwards, the union also approached the labour department for non payment of minimum wages and non payment of pending two months wages. The pending money was given but the worker was not ready to pursue the minimum wage case as she was scared of the police case. Recently, the police closed the case as the employer had withdrawn it as they located the lost chain at their residence itself. Now the union is planning to fight for back wages on the basis of minimum wage calculation that time. Now she is working in another hostel-and there has been no compensation for physical injury because of which she was unable to work for about 5 months (interview with Sr. Lizzy Jose, Secretary, AP State Domestic Workers Union, Hyderabad on $3^{\text {rd }}$ November, 2012).

\footnotetext{
${ }^{50}$ Labour department refused to acknowledge or share the details of any cases of minimum wage violation.

${ }^{51}$ Since these accounts give only a one sided version of the violations, the details needs to be corroborated for any final firm conclusion. Some of these violations have been repeated by members of other unions as well which clearly shows the prevalence of such cases. These cases though sketchy and one sided give an overview of the nature of violations and cases in the sector.
} 
Case 5.1.2. Parvathi from Kompally, Hyderabad (case reported in 2011) - Parvathi, was 55 years and working as full- time live- in domestic worker for 1.5 years with one employer. Prior to that, she had worked for many years as domestic worker in other households. She was paid Rs. 3000. She used to do all the work except cleaning. A gold ornament was missing from her employers' house and a police case was registered against her by the employer. She was taken to the police station where she fainted and was released afterwards. The son was called for questioning and the police forcefully kept his two-wheeler as a backup for the lost gold. Since one of her daughters was a member of the union she sought the help of the union to sort out the case. The union members went and met the police and asked them to return the two-wheeler which is required for the son, a plumber, to go for work. Union people also went to the employer's house and found that their allegation is baseless. The union explained to the police many similar cases and the need to understand the other side of the story also. The fact that she was not paid minimum wage was also raised alongside the practice of prohibiting her from using the toilets in the house. She had to get up at 4.00 am to go to the public toilet. When minimum wages was raised the police said that since her food and accommodation is met another Rs. 2500 needs to be added which would make the salary above the statutory minimum. However, the union then asked for overtime wages and convinced the police of looking at the matter from all sides. Accordingly the two-wheeler was given back to the son. The police case is on and the union is planning to take up the case with the labour department (interview with Sr. Lizzy Jose, Secretary, AP State Domestic Workers Union, Hyderabad on $3^{\text {rd }}$ November, 2012).

\subsection{Cases from Bihar}

In Bihar, Bihar Domestic Workers' Union (BDWU) reported of many cases related to issue of wages and overall working conditions. Normally when a complaint is received, grass root organisers visit the worker and the employer to verify the allegations. If the complaints are found correct and genuine the organisation tries to handle it at their own level through negotiation as many workers are not interested in registering a formal complaint. However, in the event of any possibility of negotiation, a formal application is sent to concerned departments. However, it was informed that there has been no positive response from the labour department and hence many cases are handled through the Minority Commission of Scheduled Caste/Scheduled Tribe (SC/ST) Department for eligible compensation.

Case 5.2.1. Anil from Assam, (case reported in 2010) - Anil aged 25 years worked in the household of a carterer - did cleaning work, shopping and helped in chopping vegetables and delivering food to different places. The employer did not give salary after a month. Since he was employed through a placement organisation ${ }^{52}$ he made a complaint to the agency and the employer was called. However he postponed the date of pay and finally the worker left the house. The organisation approached the employer but he borrowed time and did not give the salary for almost a year. The case was registered with the police station and they also went to SC/ST commission as the boy belonged to the ST Community. Some of the officials asked the organisation to go and file the case in Jharkand (the neighbouring state) as he was from that state. With regular follow up the employer was summoned by the police department and in the meeting where media people were also present the police directed the employer to pay the dues. The worker had worked for 1.5 months and a due of Rs. 3300 was paid, deducting the money

\footnotetext{
${ }^{52}$ Bihar Domestic Workers Welfare Trust
} 
that was given for his conveyance on Sundays to attend church. No penalty was given however (interview with Sr. Leema Rose, State Co-coordinator, Bihar Domestic Workers Welfare Trust, Patna on $12^{\text {th }}$ October, 2012).

Case 5.2.2. Poonam from Patna, (case reported in 2010)- Poonam, aged 35 years from Mainpura, Patna was a part- time worker with work experience of about 35 years. She took leave for a week with the permission of the employer and went to the village for a relative's marriage but could come back only after two weeks. In one house she was employed by two brothers, staying together with their families. When she came back the elder one's wife asked her to leave the job while the younger one asked her to work. Hence she continued to work in the house. However she was not paid the salary for a month. On a day when the younger sisterin-law was away she was beaten up the elder one and while resisting the assault she also pulled the employer's hair. The father-in-law who was present at the house intervened and asked the worker to leave. That evening the worker along with few fellow workers (10-12) and her husband came to the employer's house. The employers got scared and agreed to pay her due salary besides meeting the medical expenses. She was not satisfied with this settlement, because neither the wrong doer was present nor the other members in the employer's household were ready to apologise. Hence she approached the union with the help of a relative. The organisation after a round discussion with the worker decided to intervene. A case was filed in the police station and the police went to the house for inspection. The employers got scared. The worker insisted on the employer's apology and finally they apologized and paid money for her treatment and paid the wage that was due. However, no case was registered with the labour department (interview with Sr. Leema Rose, State Co-coordinator, Bihar Domestic Workers Welfare Trust, Patna on $12^{\text {th }}$ October, 2012).

\subsection{Cases from Rajathan}

The Rajasthan Mahila Kamgar union in Rajathan has taken a number of cases of non-payment or cuts in wages. As per the secretary of the union in a month one or two cases on cut in wages come to the organisation. The union is able to handle it through negotiation with the employers as the employers often agree to their conditions as they know that otherwise all other workers will refuse to work in that house. All these cases had come up in areas were the union is active. However in one of the cases, the union was approached by the worker after a failed attempt of protest by the workers themselves. The union also had intervened in the cases of domestic workers with the help of the labour department largely of child domestic workers. One such case though was initially was taken up as a case of child labour it was found that the worker was above $14 .^{53}$

Case 5.3.1. Malathi from Kooch Bihar - (case reported in 2011): Malati 35 years, a migrant from Kooch Bihar was working as a part- time worker in the house of a doctor couple. The worker because of ill-health could not come for 4 days and hence her wages were cut. She informed this to all her fellow workers in the apartment and a group of workers (8-10) protested outside the apartment. The couple took a video clipping in their mobile phone of the

${ }^{53}$ Under the Child Labour (Regulation and Prohibition) Act, 1986, child labour is defined as those 14 years and below.

Conditions of Work and Employment Series No. 66 
protest and called the police. Police came and arrested all women. Union was approached for help and the union had to negotiate the case thorough the Police Commissioner. Finally no police case was registered and the workers were released and the employers' had to pay the due wages (interview with Ms. Meva Bharati, Secretary, Rajasthan Mahila Kamgar union, Jaipur, $5^{\text {th }}$ October, 2012).

Case 5.3.2. Prema from Karnataka - (case reported in 2008): Prema, aged 15 years was brought from her native place in Karnataka by the employer who worked with Reliance Company as Manager. Her mother through a middleman took an advance and put her to work in this house when the employer was in Bangalore. The employer has shifted from Karnataka to Lucknow and then to Jaipur. She worked in the house for about 2 years and few months. A female press reporter noticed her in the apartment park since she looked different and mistook her as a child labour. When approached the worker explained to her the exploitation and ill treatment at the employer's house. She also showed a wound which was due to the physical violence. The reporter informed the union and the union members along with labour inspectors, police and media went to the employer's house to rescue her, thinking that she is a child labour. The girl was rescued and was put in a rescue home since her family could not be located. An FIR was filed though the employers resisted by putting pressure on the police and the labour department. The employer finally gave Rs. 100,000 as compensation - the amount was arrived at using minimum wage calculation and penalty engaging child labour. The money was put as fixed deposit in her name. With the help of an NGO in her native place her parents were traced and the mother was brought to Jaipur and the girl was sent with her. In this episode, secretary of the union which reported the case felt that the labour department was not cooperative in settling her wage dues (interview with Ms. Meva Bharati, Secretary, Rajasthan Mahila Kamgar union, Jaipur, $5^{\text {th }}$ October, 2012).

Case 5.3. Veronica from Assam - (case reported in 2011): Veronica, aged 19 years was working in the house of an Army Officer for more than 2 years. The employer had brought her to Jaipur when he got transferred from Assam. During her stay with the family she was not given any salary and was not allowed to go anywhere. She taking the help of another domestic worker got in touch with the union. The union with the help of the labour department got her released. However, the employer was powerful and was not ready to pay the wages due to her. The union registered a complaint under Minimum Wages Act, 1948. However, the labour department did not show any interest. The department tried sorting out the issue with a compensation of Rs. 20,000. But the girl did not agree for the amount and she was ready to fight for her full dues. The union took the help of a lawyer and the case went to the labour court and the employer also put a lawyer to defend his stand. During the court trial some discrepancy between the workers first statement and the subsequent detailed statements was pointed out and exaggerated by the defence lawyer. The union argued that the first statement was made under fear at a time when she was just released from the employers' home. There were detailed trails but the worker replied to all questions confidently. The case was long stretched and finally the union sent a formal complaint to the army head quarters. After this, the employer showed readiness to settle the matter in the court. A compensation of Rs. 155,000 was made which was calculated on the basis of minimum wages and penalty for violation of provisions of Minimum Wage Act, 1948 (interview with Ms. Meva Bharati, Secretary, Rajasthan Mahila Kamgar union, Jaipur, $5^{\text {th }}$ October, 2012). 


\subsection{Cases from Karnataka}

In Karnataka also some instances of non- payment of wages and cases of violation of the provisions of MWA was reported. The most sought strategy by workers to address this issue was leaving the employer who paid less. Workers expressed fear in taking these matters with unions as they thought this would affect their employment in other houses as well. Further many suggested that they did not have time to follow it up. In the discussion with unions many cases of child domestic workers were reported. In the context of minimum wage violation, though there have been some cases, the organisations were found handling those at their own level. In one of cases handled by one of the unions the employer promised the worker that the salary would be kept in the employer's bank account and will be paid to her when required. But when the worker asked for the money for treatment of her husband the employer refused to give. On the contrary, she was threatened of a police case by the employer. The organization took up the case and through various sittings negotiated for payment of dues. The organisation settled for an amount lower that what was due to her as per the minimum wage stipulation, as the worker needed the money urgently. (interview with Ms. Shahataj, Organiser, Women's Voice, Bangalore, Karnataka on $9^{\text {th }}$ August, 2012). In yet another case, one domestic worker who broke few ceramic plates while washing was punished by denying salary dues for 3 months. This case was also negotiated with the employer and finally the wages were paid to the worker (interview with Ms. Shahataj, Organiser, Women's Voice, Bangalore, Karnataka on $9^{\text {th }}$ August, 2012).

According to an organiser in Bangalore, "The Labour Department is not keen in interfering even when complaints are taken to them. Further, the long process in any settlement dissuades workers and they do not have any trust in the department" (Sr. Ceila, State Co-ordinator, Karnataka Domestic Workers Union., Bangalore, Karnataka, interviewed on $7^{\text {th }}$ August 2012). During the course of data collection, 2 cases have been reported by the organisations which were registered with the labour department. Surprisingly these cases were not mentioned in the discussion with the concerned officials who denied of any case of minimum wage violation.

Case 5.4.1. Aruna from Chittoor - (case reported in 2009): Aruna, aged 20 years, has been working for almost a year in the house of a liquor contractor who is also a politician. She was not paid a salary for 8 months. Since she had a bank account and the money was remitted for 2 months in that account by the employer the organisation could prove the case. Case was taken up in the labour court and the worker was paid a compensation of Rs. 40,000. It took almost a year for settlement and the girl got frustrated. The wages was calculated as per minimum wage provisions but only for 8 hours per day. She was a live-in worker; however no overtime wages were given. The organisation feels that the Labour department did not take a proactive role in the case which led to this poor settlement amount (interview with Ms. Geeta MenonCoordinator, Stree Jagruti Samiti, Bangalore, Karnataka on $8^{\text {th }}$ August, 2012). 
Case 5.4.1. Papamma from Hyderabad - (case reported in 2010): Papamma, aged 60 years worked as domestic worker in a house in Bangalore for almost 30 years as a full time live -out worker. She was discharged abruptly with no provision for retirement. Papamma received a wage of Rs 60 for 22 years, for eight hours of work a day where she combined all tasks. In 2003, her wages were raised to Rs 500 a month. In 2007, before her dismissal, for few months she was paid Rs. 1500 following repeated requests. After dismissal she approached the Karnataka Domestic Workers Union which took up the case with the help of a group of advocates. A case was registered against the employer. The litigation was on for one-and-ahalf years. Finally, the court took a favourable judgement, and the employer was made to pay the dues calculated on the basis of the minimum wage provision from 2004 and compensation equalling the amount of back wages as well as overtime for all the Sundays when she had worked. The role of the labour officer in his case was critical in getting a favourable judgement (interview with Maitreyi Krishnan, Advocate, Alternative law Forum, Bangalore on 8th August, 2012; details are available on line at http://infochangeindia.org/livelihoods/features/papamma-s-victory-marks-a-milestone-in-thedomestic-workers-struggle.html).

From the analysis of the above cases it is evident that violations of minimum wages are often reported and taken up as subsidiary and residual issues. It is only when other issues such as denial of wages, dismissal, alleged theft, harassment and physical abuse or workers are raised some attention is given to the aspect of non-payment of minimum wages and other provisions of MWA. 


\section{Chapter 6. Impact of minimum wage legislation}

The most persistent argument which has been posed against minimum wage setting, not only for this sector, but also for other informal sector as well is that of workers losing employment because of a mandatory minimum wage though there have been no empirical basis for a such a position. The assumption behind such a position is that it is the cheap labour aspect of this sector that attracts employers. In Karnataka the Act has been in place for about 8 years now while in Andhra Pradesh and Bihar it is about 5 years. This substantial period of existence of the minimum wage in various states provides one with reasonable insights on its implications of employment outcomes. In the context of domestic workers the employment impact of minimum wage seems to be contrary to the existing understanding on the subject. In all the states studied, discussions with various stake holders have revealed an increasing demand for domestic workers over time even after the issue of notifications on fixing as well as revising minimum wages. It seems that apart from minimum wage regulation, there are other factors that determine the demand for workers. The expansion of middle class, the nuclearisation of families coupled by women's entry into the labour force from these classes seems to have increased the demand for domestic workers over the years (Neetha \& Palriwala, 2011). Further, technological improvements in household work during the period have not been adequate enough to replace the cheap labour of the domestic worker.

While the above findings remain, two aspects need to be noted in the context of any discussion on minimum wages and its employment impact. Firstly, minimum wages in all the states are fixed at rates lower than the market wage in urban areas ${ }^{54}$ which in any case does not hinder many employers from employing workers. Further, the level of awareness and compliance is very poor among workers as well as employers. This along with restriction and apathy in enforcement of the legislation is a concern. ${ }^{55}$ Thus the issue which is more important in the case of domestic workers is as to whether the existence of a minimum wage which is never or poorly enforced could lead to any change in wages and other conditions work. The experiences of the states where minimum wages have been prevalent for some years can throw useful insights on these dimensions.

During discussions with workers, member of unions/organisation, officials and other stake holders' information on various parameters like market wage, mode of payment, wage period, leave situation, over time wages and so on were collected, which could throw some light on some of the impacts of the legislation.

\footnotetext{
${ }^{54}$ In general, the market wage rate for domestic work in cities, where there has been an increase in demand for domestic workers, is higher than that of minimum wage.

${ }^{55}$ Detailed discussion on the restriction and disinterest is evident from the discussions in the following chapter.
} 


\subsection{Market Wages of Domestic Workers}

While the statutory wages are time rates, market wage rates for part time workers are calculated across tasks in all the states studied. There are difficulties in comparing task based wage with a time rate wage in the context of part time workers as the details of the tasks differ from one house to another depending on the household profile such as number of members, age of members, area of the house, and so on . Given these limitations, an attempt was made to convert the task based market wages to time rate. It is found that the market rates are generally higher than the statutory wage in all the cities covered. However, even in the capital cities of the respective states there were some cases of workers who are paid less than the minimum wages. Further, many workers who were getting higher market wages opined that they deserved better wages as their working hours were often stretched as they are often made to do additional tasks without any payment. Further, the market wage differed across locations in the city and sometimes areas in close proximity to one another show significant differences in wage rates. This difference could be attributed to the socio-economic conditions of the employers that they are employed with, their migration status (local versus migrant; new migrant versus old settled migrants), socio-economic conditions of workers (their caste, employment status of male members, household profile etc.).

Table 6.1. Comparison of minimum wages for domestic work with market wages

\begin{tabular}{|c|c|c|c|c|c|c|c|c|c|c|}
\hline \multirow{2}{*}{$\begin{array}{l}\text { Tasks/ } \\
\text { category }\end{array}$} & \multicolumn{2}{|c|}{ Karnataka } & \multicolumn{2}{|c|}{ Andhra Pradesh } & \multicolumn{2}{|l|}{ Bihar } & \multicolumn{2}{|c|}{ Rajasthan } & \multicolumn{2}{|l|}{ Kerala } \\
\hline & $\begin{array}{l}\text { Market } \\
\text { Wage }\end{array}$ & $\begin{array}{l}\text { Statutory } \\
\text { Wage }\end{array}$ & $\begin{array}{l}\text { Market } \\
\text { Wage }\end{array}$ & $\begin{array}{l}\text { Statutory } \\
\text { Wage }\end{array}$ & $\begin{array}{l}\text { Market } \\
\text { Wage }\end{array}$ & $\begin{array}{l}\text { Statutory } \\
\text { Wage }\end{array}$ & $\begin{array}{l}\text { Market } \\
\text { Wage }\end{array}$ & $\begin{array}{l}\text { Statutory } \\
\text { Wage }\end{array}$ & $\begin{array}{l}\text { Market } \\
\text { Wage }\end{array}$ & $\begin{array}{l}\text { Statutory } \\
\text { Wage }\end{array}$ \\
\hline Cleaning & $\begin{array}{l}600- \\
1000\end{array}$ & 810 & $\begin{array}{l}400- \\
700\end{array}$ & 565 & $\begin{array}{l}300- \\
500\end{array}$ & 524.4 & $\begin{array}{l}600- \\
800\end{array}$ & 626.4 & $\begin{array}{l}1500- \\
3000\end{array}$ & 787.50 \\
\hline Cooking & $\begin{array}{l}800- \\
1500\end{array}$ & 810 & $\begin{array}{l}700- \\
1500\end{array}$ & 565 & $\begin{array}{l}300- \\
1000\end{array}$ & 524.4 & $\begin{array}{l}1000- \\
1500\end{array}$ & 626.4 & $\begin{array}{l}2000- \\
4000\end{array}$ & 834.60 \\
\hline $\begin{array}{l}\text { Full time } \\
\text { Live- out }\end{array}$ & $\begin{array}{l}4000- \\
6000\end{array}$ & 4967 & $\begin{array}{l}3000- \\
5000\end{array}$ & 4521 & $\begin{array}{l}1000- \\
2500\end{array}$ & 3749 & $\begin{array}{l}5000- \\
8000\end{array}$ & 4342 & $\begin{array}{l}5000- \\
10000\end{array}$ & 3549 \\
\hline $\begin{array}{l}\text { Full time } \\
\text { Live- in }\end{array}$ & $\begin{array}{l}4000- \\
6000\end{array}$ & 4967 & $\begin{array}{l}3000- \\
5000\end{array}$ & 4521 & $\begin{array}{l}1000- \\
3000\end{array}$ & 3749 & $\begin{array}{l}3000- \\
6000\end{array}$ & 4342 & $\begin{array}{l}5000- \\
8000\end{array}$ & 3549 \\
\hline
\end{tabular}

Source: Field data, 2012 and table 2.3.

Highest wage rates were reported in the Southern states with Bangalore showing the maximum. However even in Bangalore considerable dispersion was found across areas and also between live-in and live-out workers. Based on discussions with the concerned stakeholders an attempt was made to arrive at a wage range for comparison across tasks and categories of workers. In Bangalore, the normal range of piece rate wages for cleaning tasks ${ }^{56}$ carried out on part time basis ranged between Rs. 300 to

\footnotetext{
${ }^{56}$ Cleaning tasks is broadly divided into different categories such as sweeping and moping house, cleaning utensils and cleaning clothes. However, cleaning task as it is popularly used often include only house cleaning and dish cleaning and not
} 
1000 per month. The average time spent on any cleaning tasks range between 30 minutes to 1 hour per day. The corresponding statutory minimum wage range for this task for the above duration is Rs. 405 Rs. 810. Cooking fetched higher wages, Rs. 800-1,500 per month, with an average working hour of 1 hour per day. Here the lower range corresponds to the statutory minimum wage which is Rs. 810 for an hour. The wages were bargained not according to time spent but according to task. Size of the household and number of members in the household was reported to be important parameter in negotiating wage rates. For full day live-out workers who combined multiple tasks the wages ranged between Rs. 4,000-6,000 per month. The statutory minimum wage for 8 hours of domestic work excluding child care for Karnataka is Rs. 4967/-. From the above market wage range it is clear that some workers are not getting minimum wages even if one assumes that the worker is working only for 8 hours. In new residential areas occupied largely by IT based employees domestic workers wage rates were reported higher, due to the increase demand for workers and also employer's better paying capacities. Live- in workers' wages were also found roughly similar to that of live-out full timers.

However, all the unions/organisations reported of considerable difference in wages across rural and urban areas, and within urban areas between small towns and cities. Wages in rural areas and small towns were reported to be very low. In small towns, for 8 hours of work many are only paid Rs. 1,000 per month. Domestic workers are largely hired only for cleaning operations in rural and smaller towns, with cleaning operation fetching only a monthly wage of Rs. 100-400 per household on the higher side. Many of these workers work on an average 1-2 hours a day in one house and do not have any weekly offs/rest days. ${ }^{57}$ Clearly, even the highest wage brackets are below the statutory minimum wage, pointing to many violations of the Act in these pockets.

In Hyderabad, as in the case of Bangalore wages differed across tasks among part time workers. While the wage brackets for daily cleaning work was Rs. 200-700 per month, the same for cooking was Rs. 350-1,500 per month. The average time spent on any tasks range between 30 minutes to 1 hour per day. The statutory minimum wage rate for this time period is Rs. 284 and Rs. 565 respectively. Full time live-out workers' wages were found higher than that of live-in workers, with the former showing a wage range of Rs. 3,000-5,000 per month. However, in few posh pockets the rate even touched Rs. 8000. The system of live-in workers it was reported to be less in Hyderabad, compared to Bangalore. Here again wages in rural areas and smaller towns was reported to be lowest, much below the minimum wage. In Kerala, wage rates differed across categories of workers and tasks assigned. In general wage rates were reported much higher than the minimum wage, owing to the acute shortage of workers. Full time live- out workers were reported to be maximum in demand with their wages ranging from Rs. 5,000-10,000. Specialised care workers (live-in) were also reported commonly with wages pitched at

washing clothes. Washing clothes is usually separated from other cleaning tasks, though sometimes all the cleaning tasks are taken together while fixing the wages.

${ }^{57}$ In addition to the wages, some workers may get some food and/or old clothes, credit etc. 
much higher rates. Part time work as seen in other cities was absent in Trivandrum largely due to the shortage of workers. Domestic workers who work in many houses doing daily cleaning work were reported fetching Rs. 500-1,000 per month for one cleaning task, ${ }^{58}$ depending on the size of the house and number of members. Part time workers engaged in cooking were minimal as per unions. The rates for cooking, if any, were suggested to be higher than that of cleaning tasks in the range of Rs. 2,0004,000 per month. Further, though some difference was noted between cities and small towns in terms of wage rates the difference was not very high. However, personalisation of the relation ${ }^{59}$ and the existence of non-cash benefits and incentives were higher in small towns.

In Rajasthan and Bihar, the wage rates did not show such wide dispersion though differences existed across areas. The demand for part- time workers was largely for cleaning operations; cooks are rarely hired on part time basis. ${ }^{60}$ Male part time cooks are paid better compared to their female counter-parts, the reason given being that they could combine other tasks such as shopping, fetching children and other odd demands etc. While male part time cooks earned monthly wages of Rs. 500 to 1,000 for daily one hour work, the same for women was Rs. 300-700. The monthly wages for cleaning tasks in Patna ranged between Rs. 150-500 per month. Full time live-in workers were reported more common in Patna, who was brought/hired from rural areas. Men/boys are also hired as live-in workers. Wages paid to these workers were reported to be poor and in some cases only food and basic necessities were met of the individual worker. When wages are paid the rates varied between Rs. 1,000-3,000. The employment relation in these cases was more of feudal in nature with kith, kin and family networks being the basis of such recruitment. Full time live-out workers fetched slightly lower wages Rs. 1,000- 2,500.

In Jaipur, shortage of domestic workers was reported with only migrant women from Kooch Bihar taking up domestic tasks. ${ }^{61}$ The rates for cleaning operations though varied across localities with house cleaning fetching Rs. 300-800 for working hours of half an hour to one hour. Cooking for an hour fetched Rs. 1,000-1,500. Wages for 8 hours work or more was reported to be between Rs. 5,000-8,000 per month. Live-in workers fetched lower wages, Rs. 3,000-6,000. However, in the suburbs of the city the rates were reported lower with feudal patron client relationship dominating the negotiation of wages.

In none of the states studied, the statutory rates were found to be a central reference point in the determination or fixing of wage rates at the overall level as in the wide variation of wages discussed above. The wage setting and revision though are individual based; there is an informal collective understanding that influences the rates, directly or indirectly. This is important in understanding the

\footnotetext{
${ }^{58}$ In Kerala, unlike other states, cleaning task is further divided into cleaning floors and washing utensils and the rates are negotiated separately.

${ }^{59}$ Some are reminiscent of feudal patron-client relationship, while others are based on caste/religious and political identities.

${ }^{60}$ In Patna, female domestic workers are locally called as Dais and the term has a demeaning status.

${ }^{61}$ No local worker likes to be called as 'bhai'. Bhais is the local name for domestic workers and a low social status is attributed to bhais in general. 
impact of minimum wages on the market wage of domestic workers. Workers who were part of unions/organisations said awareness on the same was always there at the backdrop while wages were negotiated. This was true even when these workers were employed at higher wage rates, than the minimum wages. This gave them some floor level and confidence to negotiate better wages. The fact that a section of the employers also knew about the existence of a minimum wage was also reported to have eased the wage negotiation process for many workers. ${ }^{62}$ Thus it seems that the mere existence of minimum wages strengthens the bargaining position of workers, even when stake holders are unclear of the exact provisions.

Unions/organisations though were critical of the lower rates of the statutory wage, reported of the indirect impact that the Act had on wages in general. Market wages had increased over time in the cities. In Andhra Pradesh, the wage rates have increased over the last few years -3 years before the wage rate for cleaning for an hour was Rs. 300 per month - now the same has increased to Rs. 700 . Though this is largely due to the increased demand for domestic workers, and their informal bargaining capacity, the existence of a statutory minimum wage was reported helping some workers (who are linked to unions/organisations or with some awareness) to bargain for higher wages thereby enhancing the overall wage standards for others to follow. This ripple effect, though invisible often lead to situations of implicit bargaining where a growing informal consensus among workers is arrived at regarding a possible wage revision. However, clearly there are differences among states with workers from some states being able to use the statutory wage to their advantage much more than others. Here the degree of collectivity and unionisation are important parameters.

In all the states studied workers are largely paid in cash. In-kind payments if any are over and above the cash payment. During festivals, sarees and other gifts are given. Even in small towns wage payment in cash was reported to have become the norm.

\section{Domestic Workers Wages compared to comparable categories of work in the informal sector}

Analysis of minimum wages across other comparable sectors of employment helps in the social and legal devaluation of domestic work. The biggest challenge in doing so is to come up with a comparable occupational category. Other employment within private holds has yet to make the list of scheduled employment in all the states studied except Kerala. In Kerala, as explained in the previous chapters, there is a hierarchy of such jobs in terms of minimum wages with cleaning tasks at the bottom. Categories such as driving, gardening and security guards are placed at the top of the hierarchy definitely reflecting the social hierarchy with gender being one central axis. Cleaning and sweeping takes place outside the premises of the household as well, with many workers involved in the cleaning

${ }^{62}$ Some workers however expressed fear of the possibility of statutory minimum wage being used by employers to push down the wages. 
of roads and public places. Though the nature of the workplace is different, the description of work is comparable and could be used to understand the discriminatory nature of the state in fixing minimum wages.

Table 6.2. Minimum wages of domestic workers compared with comparable informal sector employment

\begin{tabular}{|l|l|l|l|}
\hline & Domestic work & $\begin{array}{l}\text { Sweeping and cleaning } \\
\text { workers }\end{array}$ & $\begin{array}{l}\text { Construction work - } \\
\text { unskilled }\end{array}$ \\
\hline Karnataka & & $\begin{array}{l}225.38 \text { for Zone A; 195.38 } \\
\text { for Zone B; 165.38 for Zone } \\
\text { C. }\end{array}$ & $172.58^{*} \& 171.01^{* *}$ \\
\hline Andhra Pradesh & 165.58 & 260.56 & 197.31 \\
\hline Bihar & 173.85 & 157 & 157 \\
\hline Rajasthan & 144.62 & 147 & 147 \\
\hline Kerala & 167.08 & $286.05^{*}$ & 178.46 \\
\hline
\end{tabular}

Source: State Gazettes

* Lowest wage for an all inclusive 'other categories' notified for the sector.

**Lowest among unskilled categories for zone I \& II; the wages for unskilled workers in Municipality and Corporation is higher

Another way to look at the issue is to compare minimum wage of domestic workers with occupations that these women workers would have taken up in the absence of domestic work. One such occupation is construction work. In construction, women are largely in unskilled work ${ }^{63}$ and hence the minimum wage given in the table is that of unskilled work. ${ }^{64}$

The table is self revealing, clearly bringing the devaluation fore-front. Except for Rajasthan, the minimum wage for domestic work is fixed at rates lower than that of sweeping and cleaning workers, who are employed by local administrative bodies or private employers to perform tasks outside private households. This exception in the context of Rajasthan which could be because of the unions' continuous campaign in Rajasthan opposing the categorisation of domestic work as unskilled work (see Rajasthan Annexure- 4). Minimum wage revision took place after these campaigns, which according to the union leader influenced the wage setting (Interview with Ms. Meva Bharati, Secretary, Rajasthan Mahila Kamgar union, Jaipur, $5^{\text {th }}$ October, 2012).

\footnotetext{
${ }^{63}$ Interestingly in the Bihar notification, domestic workers are categorised as unskilled workers with an explanation on unskilled work- Unskilled work means work which involves simple operations require little or no skill or experience on the job (Bihar Annexure -1).

${ }^{64}$ The actual wage in construction is higher. However, number of days of employment is an issue as it is highly variable. Because of the uncertainty in employment in construction many construction workers have shifted to domestic work and in some cases workers take up both simultaneously. In Andhra few domestic workers reported that they have taken up domestic work only 1 or 2 houses in the morning after which they go for construction work if it is available. They expressed readiness to remain in construction work if there was job security as the wages are higher compared to domestic work and the work was socially more acceptable.
} 


\subsection{Hours of Work, Overtime Pay, Weekly Day of rest and Other Benefits}

'Hours of work' in general is a contentious issue among workers. In the discussions with workers and unions/organisations it was evident that the provisions on working time were violated in the states. A large section of the workers complained of extended working hours with additional tasks (outside the contract) assigned to them almost regularly. For part time workers, this meant running from one house to another under the constant tension of being late not only in subsequent houses but also for their own household chores. Workers complained that employers have no understanding of the formers' time and responsibilities such as housework, taking care of children and other household errands. Daily hours of work of part time workers varied from 3 hours to 12 hours in these states depending upon the number of houses in which they were employed. Thus for a section of part time workers, the average hours of work on a day exceed the normal working hours of 8 hours a day. Full time, live-out workers worked daily for 6 to 12 hours on an average with the bulk concentrated at the upper end. Since live-in workers as are on call throughout the day, the average working hours was reported highest at 14-18 hours per day.

Only in two states overtime wages have been specified in the minimum wage notification - Karnataka and Rajasthan. However it is difficult to calculate overtime provisions in the case of part time workers as multiple employers are involved. No payment is given for additional work outside the contract which is a regular phenomenon. Informal systems of additional cash wages or wages in kind were reported for longer hours of work which are intermittent arising out of festivals, family functions etc. However, this was not true in all cases. Further, the provision of 'extra payment' did not follow any standard and is purely at the discretion of employers. There were state/area differences, along the same lines as discussed in the context of wages and weekly rest days. ${ }^{65}$ Overtime payments were raised as issues by unions/organisations in the context of live-in workers also. However, since the law has been ambiguous on the specificities of live-in workers, unions/organisations were also not in a position to push this provision even when some of the organisations do placement services for workers.

Weekly rest days were found to be an important issue across all the states though with varied intensity. ${ }^{66}$ Kerala was the only state where weekly rest day was not raised as an issue by organisations and workers. The six-day week was found to be the norm across all the sectors in the state and domestic workers enjoyed the spill over of this general practice, even before the extension of the minimum wage legislation.

\footnotetext{
${ }^{65}$ Since in certain areas there is a shortage of workers and given the difficulty in getting a worker with whom a personal relationship could be built (which would demand time), employers were reported to be more accommodating and cooperative in general regardless of the provisions of the Act.

${ }^{66}$ Weekly minimum rest period specified in the ILO convention (C. 189) is 24 hour continuous break.
} 
In other states, workers in general were denied wages and only a few could avail weekly off/rest day as per the provision. Most workers did not have any weekly rest days. However, the situation was found better in Bangalore and in certain pockets of Hyderabad. Workers who were part of unions/organisation and were aware of the leave provisions could negotiate the same with employers. While few workers could negotiate for weekly rest days some could get only 2-3 rest days in a month. One or two rest days in a month were given without much resistance but if they took more than that wages were cut. During discussions with workers it was evident that awareness on provisions for compulsory weekly offs/rest days was critical in negotiating for rest days as a right. However, many who were unaware of the provisions had to negotiate rest days with employers on a personal basis. Thus the right to rest days is construed as a prerogative of the employer and not as a right of the worker. Workers also did not see leave as their right. Some workers could take one or two leaves in a month with the knowledge of the employer without any problem. However, in many cases compulsory weekly off was denied and instances of cuts in wages were also reported. However, in Patna absence of weekly offs/rest days was the general rule with some exemptions. In Jaipur very few workers got a weekly off/rest day, while the majority worked continuously. In the event of leave, wages were cut. Even when wages were not cut, many workers highlighted verbal scolding and abuse. Less than 10 percent of workers were given leave without scolding. ${ }^{67}$ Taking weekly off/reset day on a Sunday was found difficult as many workers had to do more work on that day. Many workers reported their preference of not taking any day-off if possible as they were often asked to do extra work to compensate for the day's work to which they did not attend. In some cases the extra work could be the piled-up work of previous days such as dirty utensils and clothes but in some cases this could also be additional work such as cutting vegetables, folding clothes, cleaning curtains and linens etc. even prior to the granting of leave. The issues of unionisation in general and the inability of existing organisations/unions to get across a large section of the domestic workers and to negotiate with a feudal structure are issues in the context of these states.

Though weekly day-off/rest day is an issue across many states at different degrees, the situation was reported to have improved over time with some workers managing to take a few rest days. As in the case of wage setting, a small section of vanguards, who are aware of the statutory provision, set replicable standards. As per organisations/unions in certain specific locations in the city of Karnataka and Hyderabad, leave (at least 2 days in a month) overtime is emerging as a practice. In these areas, because of their intervention a small segment of domestic workers have started demanding for eligible compulsory weekly offs. Employers ${ }^{68}$ had initial resistance in granting weekly offs, but eventually came to terms with this condition. Though the same is true only for tiny and scattered islets (even with few exemptions within), the credit of these positive spurts is to a large extent attributable to the statutory

\footnotetext{
${ }^{67}$ Workers reported of many cases where some of them have lost employment - for availing leave without permission of the employer or because of extension of leave.

${ }^{68}$ As a prelude, employers through workers are given pamphlets/notices of the organisation/union stating minimum wages and conditions of work. 
provision and its awareness. The role of unions/organisations in creating awareness on the provisions is critical.

Annual leave, medical leave and maternity leave are not extended to domestic workers in any of the states. These are negotiated at an individual level and it is rare to find workers who have paid annual leave or maternity leave. In many cases, workers have to get a substitute worker during their days of leave to ensure continued employment after such leaves. Short medical leaves of a day or two, not so frequent (2-3 times a year) are common but any extended leave beyond this is sure to invite wage cuts.

Other provisions in the Act if any, which varied across states, did not figure in the discussions either with workers or unions/organisations, which is expected in the context of violations of the central elements of the Act.

\subsection{Status as Workers and Possibilities of Unionisation}

The most important outcome of the existence of minimum wage legislation is that it gave domestic workers the status of workers. The recognition of domestic work as work by the state through the extension of the Act has definitely made a change in the general understanding of domestic work. To quote an organiser from Andhra Pradesh, "Extension of minimum wages to domestic workers though has not made much difference to the actual wage situation it has definitely led to the recognition of domestic workers as workers. Finally, they have been given the status of a worker" (Interview with Br. Varghese, Director, Montfort Social Institute, Hyderabad, Andhra Pradesh on $5^{\text {th }}$ November 2012). Another organiser from Karnataka stated "Recognition of domestic workers as workers is importantthat is why minimum wage legislation is critical" (Interview with Ms. Laliamma Mathew, Akhila Karnataka Domestic Workers Trade Union on 3rd November 2012). In the interaction with workers too, their inclusion in this labour law was conceived as an achievement leading to better social status. One domestic worker aged 65 working since 13 years shared the following "I never knew that minimum wage existed and we are workers till recently. I have never got minimum wage - but the future generation should get it - it is their right" (Vijaya Nagaramma, domestic worker, Hyderabad on $5^{\text {th }}$ November, 2012).

The fact that domestic workers do not come across as clear well-defined part of the labour force has affected the collectivization of workers. Domestic workers have entered into the unions only recently, which is clearly linked to the extension of the Minimum Wages Act, 1948. Earlier, domestic workers organisations in many states were not allowed to register under the Trade Union Act as none of the labour laws were applicable to them. With the extension of Minimum Wages Act, 1948 registered trade unions of domestic workers have emerged in all the states studied with Karnataka having the highest 
number. ${ }^{69}$ Apart from this, existing trade unions which never considered this sector as their area of intervention ${ }^{70}$ have also initiated organisation of domestic workers. In all the states covered, many central trade unions have taken up the agenda of organisation of domestic workers in a big way. In some states, under the existing trade unions, separate unions for domestic workers were also found registered.

${ }^{69}$ As per discussions with union members in the state there are 8 registered labour unions of domestic workers.

${ }^{70}$ Trade unions were reluctant to organize domestic workers earlier. As per one organizer in Kerala, trade union leaders used to neglect the issues of domestic workers by saying that women working in the state welfare programmes such as ICDS (Integrated Child Development Scheme) and teachers in the informal sector are more exploited than domestic work'. Now however, the attitude is changing with the minimum wage legislation. 


\section{Chapter 7. Conclusion}

In India, in recent years, protection under Minimum Wages Act, 1948 has been extended to domestic workers in few states in the country. The present study looked at the procedures and processes involved in the fixation and revision of minimum wages in these states. Alongside a comparative analysis of the rates and other related conditions of work across states the study assessed the functioning of the legislation with a view to draw lessons from these experiences. Some broad issues of implementation such as lack of awareness among various stakeholders and specific enforcement issues were also captured. These experiences of various states provide useful insights for formulating guidelines towards effective regulation of domestic work in future.

\subsection{Summary of Findings}

Some of the key findings that emerge from the study are:

1. Different states have extended minimum wages to domestic work in different years. Procedure, process and method of wage fixation did not vary much among the states. The study suggests that the processes in the states studied are characterized by absence or little consultation with domestic workers, employers or with organizations working among domestic workers. In states, where some consultation happened it was found that these were partial and selective. Further, low levels of deliberation characterized the consultation. Even in the Minimum Wage Advisory Boards, the members seem to have a lack of clarity on the criteria and bases for setting the minimum wage levels and other conditions of work in the sector.

2. Minimum wage legislation in all the states followed a task based approach. The definitions of the tasks included in the notification are informed or guided by the traditional understanding of house work (which is often shared by a large section of workers, union leader, employers and labour officials). Thus, in all the states, except Kerala, the tasks mentioned in the notification were strictly women's traditional house work tasks such as cooking, cleaning and nonspecialised care work.

3. There are reservations among unions and organisations working among domestic workers on the inclusion of specialized care tasks and tasks such as gardening, ironing, driving etc. into the minimum wage notification for domestic work. These reservations, more than the practical difficulties (given the gendered division in domestic work tasks) of a broader definition on women domestic workers, are based on the social understanding of domestic work. Many workers, employers, labour officials and even some union leaders consider domestic work as a non- technical occupation. 
4. Statutory minimum wage varied across states. While some states have notified uniform wage rates for all tasks that are listed in the notification some states have differentiated the rates across tasks. Within a general devaluation of housework as women's work, the rates for various categories of housework work are influenced by the social understanding of that task. The skill underlying each task not only has a gendered understanding but is also rooted in caste divisions and the minimum wage rates of some of the states are defined accordingly. Wage rates for cleaning which is largely carried out by women from lower social strata is pitched at the lowest wherever task base differentiation is followed.

5. In all the states except Karnataka, the current minimum wage rates are notified for a day (i.e. daily rates). Andhra Pradesh, Bihar and Rajasthan and Kerala give wages rates for 1 hour and 8 hours while Karnataka has notified monthly wage rates. All the notifications specify normal working hours of a day as 8 hours and provide for a mandatory weekly rest day. Overtime wage rates are specified only in Karnataka and Rajasthan. None of the states specify eligibility for annual paid leave.

6. The notified wage rates are low across states, with Kerala showing the lowest rate. The social understanding of housework as women's work and of less skill has affected the valuation of domestic work and hence wages setting. Domestic work is treated as unskilled work across all the states and minimum wage rates are largely lower than that of comparable employment.

7. The poor statutory wages for domestic work, in general, tend to disadvantage part time workers, who are the largest and visible segment in the occupation. As hourly wages do not match the work intensification involved in short duration employment minimum wage fixation based on piece rate is often demanded by workers and even unions/organizations.

8. The differentiation across part-time and full time workers with the latter segregated as live-in and live-outs add further intricacies at the practical level. None of the minimum wage legislations are explicit on these divisions. In most of the states, the minimum wage notification does not specify hourly wages or do not take into account the work intensification aspect of part time workers. There is also a lack of provision for overtime wages and detailing conditions of work. How to calculate and account for overtime is another issue- which is especially important in the context of live-in workers. Even in states where overtime provisions exist, there are no definite directions or provisions in the legislation regarding these. Further, there are no stipulations on maximum working hours and minimum rest hours which are important for live-in workers.

9. The average market wages of domestic workers in the urban areas of the states studied were higher than the statutory wages. However, the discussions with various stakeholders revealed that actual wages rates in rural and suburban areas were found lower than the statutory minimum wage. Payment in cash was the general practice in urban areas.

10. Minimum wages were revised in all the four states where it was due. These revisions resulted in an improvement in rates. Dearness allowance is now part of wage revisions in all the states. The 
revision simplified the task divisions and duration in some states, clearly pointing to the need to keep the minimum wages rate notification simple and easy to comprehend. In most states where revisions happened, consultations with unions or organisations working among domestic workers were held. In some of the states these consultations were crucial in wage revision.

11. The study reveals poor awareness among workers and employers on the legislation and its provisions. Even the organizations working among domestic workers were not clear about the details of the provisions, which results in the lack of specific interventions to address violations of the law. There has not been much attempt to disseminate the rates and its revision periodically among the workers and employers. The experience from the states show that even if there has been no enforcement of the legislation mere awareness on the existence of it among employers (or workers), eases the negotiation on wages. In case of violations, unless the worker is aware of the legislation; the rates and related conditions of work and the process of registering a complaint, the legislation cannot be enforced. So it is critical to spread awareness on the legislation and its provisions.

12. Unionisation among domestic workers is very weak at present in many states and they are concentrated in pockets. The focuses of organizations working among domestic workers are more on welfare schemes and labour rights of workers are often seen secondary. Organizations working among domestic workers could play a central role in creating awareness on the legislation.

13. There exists a lot of confusion, even among those who are aware of the extension of minimum wage legislation, on the actual statutory wage rates. This to a large extent is due to the complexity of the wage notification. The wages in different states are different and the tasks listed also vary. Further, the monthly rates are often given for 8 hours and for smaller durations. The task wise division of wages where it existed also adds to the confusion. The most complicated notification on minimum wage rates was that of Kerala with many divisions across tasks and duration of work.

14. The enforcement of the legislation has been week in all the states with almost complete absence of any formal complaints on violation with the labour department, though there are many cases of violation even within urban areas, where the wages are comparatively better.

15. Though there has been no direct linkage with the extension of the legislation and workers conditions of work, there have been many indirect benefits. Even with all these inbuilt limitations of the legislation, it is reassuring that there are many positive changes at the grass root level. The recognition of status as 'workers', through the legislation itself is undoubtedly the most important contribution. Further, the ripple and lagged effects of this acknowledgment are visible among few dispersed workers. Accordingly vague notions of worker rights including minimum wages are intermittently voiced and are, at times, found forming the base of informal negotiations over working conditions and wages. The study also observed existence of islands of unions/organisation interventions and their contribution in making the workers voices heard. 
Such success stories reinforce the need for legal intervention and the relevance of further strengthening the existing measures.

16. The existence of minimum wage has made significant impact on the sector, especially in terms of its social acceptance as any other informal sector work. Beyond this, there is also a need to strengthen the enforcement of the legislation without which it is not possible to ensure a decent living for domestic workers given the social, economic and political reality at the ground level. Explicit restriction on inspection and exemption of employers from record keeping exist in many states. In a sector, where workers do not themselves fully recognize their work as employment (but as extensions of their household and social roles and responsibilities), there is a need to strengthen workers' rights, through appropriate policy interventions.

On the whole, the study finds that extension of minimum wage legislation to domestic workers is viable with definite positive outcomes. The experiences of all the states suggest that arriving at a minimum wage for the sector is feasible and can go a long way in addressing some of the concerns of domestic workers. However, there are specific issues and challenges.

\subsection{Recommendations and Policy Suggestions}

On the basis of the foregoing analysis, based on insights from selected states, the following are some of the recommendations towards further strengthening MWA, 1948 and its enforcement in the case of domestic sector workers.

1. Mandatory consultation: The state should ensure regular consultations with various stakeholders while fixing/revising minimum wages.

2. Definitional clarity: The task based differentiation of domestic work could be replaced by an employment relationship based definition, which puts private households as the central focus. The task could be elaborated if required. This would make it more simple and uniform across states.

3. Desirability for National Minimum Wage for Domestic Work: To protect the interest of domestic workers and to bring overall uniformity in the minimum wage rates across states there is a need to fix a national floor minimum wage below which the states cannot fix the state level wages.

4. Better Minimum Wage Rates: Minimum wage rates of domestic workers should be at least on par with comparable work. The rates should also take into account the living needs of workers and their families.

5. Simplification of Rates: It may be desirable to have a flat rate for all tasks, without task differentiation. This would make the rate simple and easy to comprehend. 
6. Daily Minimum Wages could be specified for different durations: To address the specific issues of part time workers, minimum wage rates could notify daily wages for different durations of work (for example, 1 hour and 8 hours).

7. Inclusion of Variable Dearness Allowance in Wage Calculations: To address the increases in prices, inclusion of Variable Dearness allowance (VDA) should be considered in the determination of Minimum Wages. The desirable periodicity for VDA adjustment is one year.

8. Stipulating Working Hours and Minimum Rest Period: Normal working hours should be specifically mentioned as 8 hours per day. Maximum working hours and/or minimum rest periods per day should also be specified as per international norms and/or national laws.

9. Mandatory Weekly off: Mandatory weekly-offs should be assured to all categories of domestic workers, which should be a minimum of 24 consecutive hours. This would be consistent with the Domestic Workers Convention, 2011.

10. Payment of Over-time Wages: There is a need to provide for overtime wages when hours worked exceed the standard work-week.

11. Regularity in Revision of wages: Minimum wage should be revised every four years as provided for in the legislation

12. Mandatory Record Keeping for Employers: Employers should not be exempted from keeping records/ wage slips.

13. Dissemination of Wage Rates and Other Related Provisions: Minimum wage rates and related provisions should be disseminated in English as well as local languages through various sources such as local newspapers, radio, TV etc. to spread awareness among various stakeholders. Every time a revision or adjustment is made they should be widely disseminated. The Labour department, with the help of unions, could hold awareness camps in working class locations and for employers.

14. Promoting Worker Collectivity: There is a need to strengthen the existing trade unions initiatives in the sector and to promote new collective movements. This could help in creating awareness and empowering workers.

15. Sensitization of labour officials: There is a need to sensitise the labour department to the issues of domestic workers and take up the challenge of enforcement. The department could organise sensitization progammes or discussions on the legislation and ILO Convention 189. 


\section{List of people interviewed}

\section{ANDHRA PRADESH}

Brother Varghese, Montfort Social Institute, Hyderabad.

Sr. Bregit, AP State Coordinator (Domestic Workers), MFI, Hyderabad.

Mr. Prabhakar, Coordinator (Domestic Workers), MFI, Hyderabad.

Fr. John Vattamatam, Programme Director, MSI-DWFI, Hyderabad.

Ms. Jyothi, Sneha Domestic Workers Welfare Association, AIDWA, Hyderabad.

Ms. Punniavathi, CITU, Hyderabad.

Ms. Sajeeda Begum, General Secretary, Union of Domestic workers of Andhra Pradesh, Hyderabad.

Ms. Hajera Salam Vice, President, Union of Domestic workers of Andhra Pradesh, Hyderabad.

Mr. Bheem Reddy, Secretary TUCC, Hyderabad.

Mr. Varahala Reddy, Joint Commissioner of Labour, Govt. of Andhra Pradesh, Hyderabad.

Mr. G Ajay, Joint Commissioner of Labour, Govt. of Andhra Pradesh, Hyderabad.

Sr. Lizzy Jose, AP state domestic workers union, Hyderabad.

Ms.Nirmala, Coordinator, AP State domestic workers union, Hyderabad.

Ms. Ann Joseph, Coordinator, AP State Domestic Workers Union, Hyderabad.

Dr. B.V. Vijayalakshmi, Secretary, AITUC, Hyderabad.

Dr.Nimushakavi Vasanthi, Associate Professor, NALSAR, University of law, Hyderabad.

\section{BIHAR}

Ms. Sonal Sinha, Nidan, Patna, Bihar.

Mr. Chandra Prakash Singh, President, Bihar State, Gharelu Kamgar Congress, Patna, Bihar.

Mr. Narayan Purbey, General Secretary, AITUC, Garelu Kamkar Sangatan, Bihar.

Sr. Leema Rose, State Co-coordinator, Bihar Domestic Workers Welfare Trust. 
Ms. Saloni Tirki, Secretary, Bihar Domestic workers Union.

Ms. Pinky Kumari, Bihar State Gharelu Kamgar Congress, Patna, Bihar.

Ms. Gunja, Bihar State Gharelu Kamgar Congress, Patna, Bihar.

Mr. Amar Kanth, Deputy Labour Commissioner, Patna, Bihar.

Mr.Anil Kumar Verma, Statistical Inspector, Patna, Bihar.

Mr. Jha, Coordinator, Bihar State Gharelu Kamgar Congress, Patna, Bihar.

Mr. Nehal Akhtar, Secretary, Akhila Bhartiya Naukar Dai Mahasang, Patna, Bihar.

Mr. Ajay Srivastav, Coordinator, Confederation of Free Trade Union of India, Patna, Bihar.

\section{KARNATAKA}

Mr. Gurudas Bhatt, Assistant Labour Commissioner, Bangalore, Karnataka.

Mr. Jinkalappa, Joint Labour Commissioner, Bangalore, Karnataka.

Ms. Anuradha, Deputy Labour Commissioner, Bangalore, Karnataka.

Mr. Shivanna, AITUC, Bangalore, Karnataka.

Ms. Geeta Menon, Coordinator, Stree Jagruti Samiti, Bangalore, Karnataka.

Sr. Ceila, State Coordinator, Karnataka Domestic Workers Union, Bangalore, Karnataka.

Ms. Shasikala, Secretary, Karnataka Domestic Workers Union, Bangalore, Karnataka.

Ms. Prabha, Karnataka Domestic Workers Union, Bangalore, Karnataka.

Sr. Nisha Mathew, State Coordinator, Akhila Karnataka Domestic Workers Trade Union, Bangalore, Karnataka.

Ms. Laliamma Mathew, Akhila Karnataka Domestic Workers Trade Union.

Ms. Gayathri, Akhila Karnataka Domestic Workers Trade Union. 
Mr. Sreenivas Murthy, President, Bangalore Jilla Mane Kelasagarara Sangha (BMKS), CITU, Bangalore, Karnataka.

Maitreyi Krishnan, Advocate, Alternative law Forum, Bangalore.

Ms. Shahataj, Women's Voice, Bangalore, Karnataka.

Mr. Shanta Kumar, General Secretary, INTUC, Bangalore, Karnataka.

Ms. Uttaiah Muthaki, Women's Wing, INTUC, Bangalore, Karnataka.

\section{KERALA}

Ms. Nalini Nayak, SEWA, Kerala.

Ms. Narayani, District Committee member, CITU, Trivandrum.

Mr. Sreenivasan Nair, Retired Labour Commissioner, Trivandrum, Kerala.

Mr. Anil Kumar, Joint Labour Commissioner, Trivandrum, Kerala.

Mr. Veera Kumar, Assistant Labour Commissioner, Trivandrum, Kerala.

Mr. Visruthan, Section Officer, Labour Department Secretariat, Trivandrum, Kerala.

Ms. Sonia George, General Secretary, SEWA, Kerala.

Sr. Sally, Kerala Garhika Thozhilali Union, KGTU, Trivandrum, Kerala.

Ms. Bullu Roy Chaudhary, AITUC, Trivandrum, Kerala.

Ms. Kochu Thresia Joy, INTUC, Kerala.

TAMIL NADU

Ms. Sujatha Mody, Penn Thochilali Sangam, Women Workers Forum (NTUI), Chennai, Tamil Nadu.

Ms. Vahida Nizam, AITUC, Chennai, Tamil Nadu. 
Ms. Virgil D’Sami, Executive Director, Arunodaya, Chennai, Tamil Nadu.

Sr. Valar, Tamilnadu Domestic Workers Union, Chennai, Tamil Nadu.

Ms. Renuka, Director, Centre for Women's Development Research, Chennai, Tamil Nadu.

Ms. R. Geetha, additional secretary of Nirman Mazdoor Panchayat Sangam.

Ms. Latha, Perunagare Veetivalaye Thozhilali Sangham, CITU, Chennai, Tamil Nadu.

Ms. Kalai Vani, Deputy Commissioner of Labour, Chennai, Tamil Nadu.

Mr. Chandramohan, IAS, Labour Commissioner, Tamil Nadu.

\section{RAJASTHAN}

Mr. C.B.S Rathore, Joint Labour Commissioner, Jaipur, Rajasthan.

Mr. D.K. Chengani, Secretary, AITUC, Jaipur, Rajasthan.

Ms. Malathi Verman, NFIW, Jaipur, Rajasthan.

Ms. Nisha Sidhu, Secretary, NFIW, Jaipur, Rajasthan.

Ms. Kusum Saiwal, AIDWA, Jaipur, Rajasthan.

Dr. Jennei Srivastawa, Astha, Udaipur, Rajasthan.

Ms. Meva Bharati, Rajasthan Mahila Kamgar union. 


\section{References}

Government of India (2011). Final Report of the Task Force on Domestic Workers Realising Decent Work, Director General Labour Welfare, Ministry of Labour and Employment.

International Labour Organisation (2012). Domestic workers across the world: Global and regional statistics and the extent of legal protection, ILO, available at http://www.ilo.org/global/publications/books/WCMS_200962/lang--en/index.htm; accessed on 30 April 2013.

ISST (2009). Domestic Workers in Urban Delhi, Unpublished Report, Institute of Social Studies Trust, Delhi.

Neetha N. (2009). Contours of Domestic Service: Characteristics, Work Relations and Regulations, Indian Journal of Labour Economics, Vol. 52, No. 3.

Neetha N. and Rajni Palriwala (2011). Why the absence of Law? Domestic Workers in India Canadian Journal of Women and the Law, Special Issue on Decent Work for Domestic Workers, Vol. 23, No. 1.

Patnaik, Utsa (2011). How little can a person live on? The Hindu, 30 September.

Patnaik, Utsa (2012). Number Games: India's Declining Poverty Figures Based on Flawed Estimation method; Accurate Figures Show 75 Percent in Poverty in World poverty 25 August 2012, http://academicsstand.org/patnaik-poverty-line/ accessed on 11 May 2013.

Raghuram Parvati (2001). Castes and gender in the Organisation of Paid Domestic Work in India, Work, Employment and Society, Vol. 15, No. 3. 


\section{Conditions of Work and Employment Series}

No. 1 Quality of working life: A review on changes in work organization, conditions of employment and work-life arrangements (2003), by Howard Gospel

No. 2 Sexual harassment at work: A review of preventive measures (2005), by Deirdre McCann

No. 3 Statistics on working time arrangements based on time-use survey data (2003), by Andrew S. Harvey, Jonathan Gershuny, Kimberly Fisher \& Ather Akbari

No. 4 The definition, classification and measurement of working time arrangements (2003), by David Bell \& Peter Elias

No. 5 Reconciling work and family: Issues and policies in Japan (2003), by Masahiro Abe, Chizuka Hamamoto \& Shigeto Tanaka

No. 6 Reconciling work and family: Issues and policies in the Republic of Korea (2004), by TaeHong Kim \& Hye-Kyung Kim

No. 7 Domestic work, conditions of work and employment: A legal perspective (2003), by José Maria Ramirez-Machado

No. 8 Reconciling work and family: Issues and policies in Brazil (2004), by Bila Sorj

No. 9 Employment conditions in an ageing world: Meeting the working time challenge (2004), by Annie Jolivet \& Sangheon Lee

No. 10 Designing programmes to improve working and employment conditions in the informal economy: A literature review (2004), by Dr. Richard D. Rinehart

No. 11 Working time in transition: The dual task of standardization and flexibilization in China (2005), by Xiangquan Zeng, Liang Lu \& Sa'ad Umar Idris

No. 12 Compressed working weeks (2006), by Philip Tucker

No. 13 Étude sur les temps de travail et l'organisation du travail: Le cas du Sénégal. Analyse juridique et enquête auprès des entreprises (2006), by Alfred Inis Ndiaye

No. 14 Reconciling work and family: Issues and policies in Thailand (2006), by Kyoko Kusakabe

No. 15 Conditions of work and employment for older workers in industrialized countries: Understanding the issues (2006), by N.S. Ghosheh Jr., Sangheon Lee \& Deirdre McCann

No. 16 Wage fixing in the informal economy: Evidence from Brazil, India, Indonesia and South Africa (2006) by Catherine Saget 
No. 18 Reconciling work and family: Issues and policies in Trinidad and Tobago (2008), by Rhoda Reddock \& Yvonne Bobb-Smith

No. 19 Minding the gaps: Non-regular employment and labour market segmentation in the Republic of Korea (2007) by Byung-Hee Lee \& Sangheon Lee

No. 20 Age discrimination and older workers: Theory and legislation in comparative context (2008), by Naj Ghosheh

No. 21 Labour market regulation: Motives, measures, effects (2009), by Giuseppe Bertola

No. 22 Reconciling work and family: Issues and policies in China (2009), by Liu Bohong, Zhang Yongying \& Li Yani

No. 23 Domestic work and domestic workers in Ghana: An overview of the legal regime and practice (2009), by Dzodzi Tsikata

No. 24 A comparison of public and private sector earnings in Jordan (2010), by Christopher Dougherty

No. 25 The German work-sharing scheme: An instrument for the crisis (2010), by Andreas Crimmann, Frank Weissner \& Lutz Bellmann

No. 26 Extending the coverage of minimum wages in India: Simulations from household data (2010), by Patrick Belser \& Uma Rani

No. 27 The legal regulation of working time in domestic work (2010), by Deirdre Mc Cann \& Jill Murray

No. 28 What do we know about low-wage work and low-wage workers (2011), by Damian Grimshaw

No. 29 Estimating a living wage: a methodological review (2011), by Richard Anker

No. 30 Measuring the economic and social value of domestic work: conceptual and methodological framework (2011), by Debbie Budlender

No. 31 Working Time, Health, and Safety: a Research Synthesis Paper (2012), by Philip Tucker \& Simon Folkard

No. 32 The influence of working time arrangements on work-life integration or 'balance': A review of the international evidence (2012), by Colette Fagan, Clare Lyonette, Mark Smith \& Abril Saldaña-Tejeda

No. 33 The Effects of Working Time on Productivity and Firm Performance: a research synthesis paper (2012), by Lonnie Golden

No. 34 Estudio sobre trabajo doméstico en Uruguay (2012), by Karina Batthyány 
No. 35 Why have wage shares fallen? A panel analysis of the determinants of functional income distribution (2012), by Engelbert Stockhammer

No. 36 Wage-led or Profit-led Supply: Wages, Productivity and Investment (2012), by Servaas Storm \& C.W.M. Naastepad

No. 37 Financialisation and the requirements and potentials for wage-led recovery - a review focussing on the G20 (2012), by Eckhard Hein \& Matthias Mundt

No 38 Wage Protection Legislation in Africa (2012), by Najati Ghosheh

No. 39 Income inequality as a cause of the Great Recession? A survey of current debates (2012), by Simon Sturn \& Till van Treeck

No. 40 Is aggregate demand wage-led or profit-led? National and global effects (2012), by Özlem Onaran \& Giorgos Galanis

No. 41 Wage-led growth: Concept, theories and policies (2012), by Marc Lavoie \& Engelbert Stockhammer

No. 42 The visible face of Women's invisible labour: domestic workers in Turkey (2013), by Seyhan Erdoğdu \& Gülay Toksöz

No. 43 In search of good quality part-time employment (2013), by Colette Fagan, Helen Norman, Mark Smith \& María C. González Menéndez

No. 44 The use of working time-related crisis response measures during the Great Recession (2013), by Angelika Kümmerling \& Steffen Lehndorff

No. 45 Analysis of employment, real wage, and productivity trends in South Africa since 1994 (2014), by Martin Wittenberg

No. 46 Poverty, inequality and employment in Chile (2014), by Sarah Gammage, Tomás Alburquerque \& Gonzálo Durán

No. 47 Deregulating labour markets: How robust is the analysis of recent IMF working papers? (2014), by Mariya Aleksynska

No. 48 Growth with equity in Singapore: Challenges and prospects (2014), by Hui Weng Tat \& Ruby Toh

No. 49 Informality and employment quality in Argentina, Country case study on labour market segmentation (2014), by Fabio Bertranou, Luis Casanova, Maribel Jiménez \& Mónica Jiménez

No. 50 Comparing indicators of labour market regulations across databases: A post scriptum to the employing workers debate (2014), by Mariya Aleksynska \& Sandrine Cazes 
No. 51 The largest drop in income inequality in the European Union during the Great Recession: Romania's puzzling case (2014), by Ciprian Domnisoru

No. 52 Segmentation and informality in Vietnam: A survey of literature, Country case study on labour market segmentation (2014), by Jean-Pierre Cling, Mireille Razafindrakoto \& François Roubaud

No. 53 A chronology of employment protection legislation in some selected European countries (2014), by Mariya Aleksynska \& Alexandra Schmidt

No. 54 How tight is the link between wages and productivity? A survey of the literature (2014), by Johannes Van Biesebroeck

No. 55 Job quality in segmented labour markets: The Israeli case, Country case study on labour market segmentation (2014), by Shoshana Neuman

No. 56 The organization of working time and its effects in the health services sector: A comparative analysis of Brazil, South Africa, and the Republic of Korea (2014), by Jon Messenger \& Patricia Vidal

No. 57 The motherhood pay gap: A review of the issues, theory and international evidence (2015), by Damian Grimshaw \& Jill Rubery

No. 58 The long journey home: The contested exclusion and inclusion of domestic workers from Federal wage and hour protections in the United States (2015), by Harmony Goldberg

No. 60 Negociación colectiva, salarios y productividad: el caso uruguayo (2015), by Graziela Mazzuchi, Juan Manuel Rodríguez y Eloísa González

No. 61 Non-standard work and workers: Organizational implications (2015), by Elizabeth George \& Prithviraj Chattopadhyay

No. 62 What does the minimum wage do in developing countries? A review of studies and methodologies (2015), by Dale Belman \& Paul Wolfson

No. 63 The regulation of non-standard forms of employment in India, Indonesia and Viet Nam (2015), by Ingrid Landau, Petra Mahy \& Richard Mitchell

No. 64 The regulation of non-standard forms of employment in China, Japan and the Republic of Korea (2015), by Fang Lee Cooke \& Ronald Brown

No. 65 Re-regulating for inclusive labour markets (2015), by Jill Rubery

No. 66 Minimum wage setting practices in domestic work: An inter-state analysis (2015), by Neetha N.

No. 67 The effects of non-standard forms of employment on worker health and safety (2015), by Michael Quinlan

No. 68 Structural change and non-standard forms of employment in India (2015), by Ravi Srivastava 
